\title{
CAN FisCAL POLICY Help MACROECONOMIC STABILISATION? EVIDENCE FROM A NEW KEYNESIAN MODEL WITH LIQUIDITY CONSTRAINTS
}

\author{
V. ANTON MUSCATELLI \\ PATRIZIO TIRELLI \\ CARMINE TRECROCI
}

\author{
CESIFO WORKING PAPER NO. 1171 \\ CAtegory 5: Fiscal Policy, Macroeconomics and Growth \\ APRIL 2004
}

Presented At CESifo CONFERENCE ON MACRo, MONEy AND InTERnATIONAL FinANCE, FEBRUARY 2004

\footnotetext{
An electronic version of the paper may be downloaded

- from the SSRN website: www.SSRN.com

- from the CESifo website: www.CESifo.de
} 


\title{
CAN Fiscal Policy Help MaCROECONOMIC STABILISATION? EVIDENCE FROM A NEW KEYNESIAN MODEL WITH LIQUIDITY CONSTRAINTS
}

\begin{abstract}
This paper derives a New Keynesian dynamic general equilibrium model with liquidityconstrained consumers and sticky prices. The model allows a role for both government spending and taxation in the DGE model. The model is then estimated using US data. We demonstrate that there seems to be a significant role for rule-of-thumb consumer behaviour. Our model is then used to analyse the interaction between fiscal and monetary policies. We examine the extent to which fiscal policy (automatic stabilisers) assist or hinder monetary policy when the latter takes a standard forward-looking inflation targeting form. We also examine the extent to which inertia in fiscal policy and the presence of rule-of-thumb consumers affects output and inflation variability in the presence of such a monetary policy rule.
\end{abstract}

JEL classification: E58, E62, E63.

\author{
V. Anton Muscatelli \\ Department of Economics \\ University of Glasgow \\ Glasgow G12 8RT \\ United Kingdom \\ a.muscatelli@socsci.gla.ac.uk
}

\author{
Patrizio Tirelli \\ Dipartimento di Economia Politica \\ Universita' di Milano Bicocca \\ Piazza dell'Ateneo Nuovo, 1 \\ 20126 Milano \\ Italy \\ patrizio.tirelli@unimib.it
}

\author{
Carmine Trecroci \\ Dipartimento di Scienze Economiche \\ Università di Brescia \\ Via San Faustino, 74/B \\ 25122 - Brescia \\ Italy \\ trecroci@eco.unibs.it
}

We are grateful to participants at the 3rd EMU workshop on EMU and Macroeconomic Institutions held at Milano-Bicocca in November 2003, and to participants at the CESifo Macro, Money and International Finance Conference, held in Munich in February 2004. We are particularly grateful to our discussants Gianni Amisano and Rick van der Ploeg. We also wish to thank, without implicating them, Henning Bohn, Paul de Grauwe, Carlo Favero, Robert Kollman, Campbell Leith, Ben McCallum, Assaf Razin, and Axel Weber, for useful comments on this and earlier material. We are of course responsible for all remaining errors and omissions. 


\section{Introduction}

Despite the existence of a vast literature on the robustness and optimality of monetary policy rules, relatively little attention has been given to the issue of monetary-fiscal policy interactions. A number of papers have examined the interdependence between fiscal and monetary policies using New Keynesian dynamic general equilibrium models ${ }^{1}$, or game-theoretic models ${ }^{2}$, but none of these models have been tested empirically, with the exception of Muscatelli et al. (2003). In this paper we estimate a small econometric model for the USA over the sample period 1970-2001, and analyse the performance of monetary rules in the presence of fiscal stabilizers. Our structural model is based on a New Keynesian dynamic stochastic general equilibrium (DSGE) model. The innovation in this paper is two-fold. First, we extend some current DGSE models to include a wider range of fiscal policy transmission channels. Second, our model is estimated, in contrast to some attempts to calibrate or numerically simulate these models. Finally, the focus of our paper is on the way in which inertial policy rules interact with inertia in the structural model caused by the presence of non-optimising consumers and firms.

Conventional New Keynesian DSGE models (as discussed for instance in Galí, 2003) typically provide a very limited role for fiscal policy. The standard forward-looking IS curve is based on the assumption of "Ricardian" forwardlooking consumers, who have full access to complete financial markets. This assumption is contradicted by the empirical evidence on the permanent income hypothesis which supports the view that a significant proportion of consumers are non-Ricardian. Moreover, conventional DSGE models cannot rationalize the positive response of consumption to public expenditure shocks. To account for these effects, we adopt the innovation proposed by Galí et al. (2002), who assume that a fraction of households are constrained to consume out of current income. By doing so, we are also able to model the demand effect of other fiscal variables, i.e. taxes and transfers. On the supply side of the economy, to our knowledge existing empirical N-K DSGE models neglect fiscal distortions. In this paper we make a first attempt at estimating the empirical effect of the tax wedge on the Phillips curve in N-K

\footnotetext{
${ }^{1}$ See for example Leith and Wren-Lewis (2000), Schmitt-Grohé and Uribe (2001), Benigno and Woodford (2003) for an analysis of fiscal and monetary interactions in theoretical models. Perez and Hiebert (2002) and Zagaglia (2002) have experimented with DGE model simulations which include some fiscal closure rules.

${ }^{2}$ See Dixit and Lambertini $(2000,2001)$.
} 
DSGE models.

We use our estimated model to undertake a number of dynamic simulations, examining the responses of the endogenous variables (including the policy instruments) to unanticipated structural and policy shocks.

Finally, we conduct some policy analysis with our estimated models. This allows us to consider whether the introduction of endogenous fiscal policy rules markedly changes the performance of the monetary policy rule. Earlier contributions (Muscatelli et al., 2003) had found that countercyclical fiscal policy can be welfare-reducing in the presence of optimizing monetary policymakers. In contrast to this evidence, by introducing a role for taxation in the DSGE model, we find that automatic stabilizers based on taxation tend to be more efficient than those based on government spending. We also analyze the impact of inertia (persistence) in the fiscal rule and in the structural model on the performance of the monetary and fiscal policy rules, and find that inertial taxation rules tend to be more efficient than inertial government expenditure rules. Finally we confirm the results in Gali et al. (2003) that the presence of rule of thumb consumers tends to create more instability in the model (by increasing the variability of output and inflation following an inflation shock), but also find that automatic stabilizers based on taxation tend to offset the impact of rule-of-thumb consumers.

The rest of this paper is organized as follows. In the next section we will briefly survey the existing literature. In Section 3, we outline the structure of our estimated model and the empirical methodology. In Section 4, we report our estimates and examine some dynamic simulations from our estimated models, while in Section 5 we examine the performance and interaction of the monetary and fiscal policy rules. Section 6 concludes.

\section{The Existing Literature}

Much of the literature on fiscal-monetary policy interactions has focused on whether monetary and fiscal policy operate as strategic complements or substitutes. Dixit and Lambertini $(2000,2001)$ explore the interdependence between the fiscal authority and the central bank in a model where the latter has only partial control over inflation, which is also directly affected by the fiscal policy stance. They show that in equilibrium the two policy rules are complements when fiscal expansions have non-Keynesian (contractionary) effects on output and inflation. Buti, Roeger and in't Veld (2001) suggest that 
the specific form of interdependence between fiscal and monetary policies, i.e. the alternative between strategic substitutability and complementarity, should not necessarily be interpreted in terms of conflict or cooperation, and might be shock-dependent. In their model supply shocks unambiguously induce conflicting policies, whereas the opposite holds true for demand shocks.

Empirical contributions in this area are mainly based on panel data techniques and VAR analyses. Cross-sectional or panel data examine the relationship between fiscal and monetary policies over the cycle. Work by Mélitz (1997, 2000) and Wyplosz (1999) broadly supports the view that the two policies have acted as strategic substitutes over the last 2-3 decades. Von Hagen, Hughes-Hallett and Strauch (2001) find that the interdependence between the two policymakers is asymmetric: looser fiscal stances match monetary contractions, whereas monetary policies broadly accommodate fiscal expansions. Muscatelli et al. (2001) examine the interaction between fiscal and monetary policy instruments using conventional VAR and Bayesian VAR models for several G7 economies, and show that the fiscal shocks identified in the VAR have a significant impact ${ }^{3}$. They find that the result of strategic substitutability does not hold uniformly for all countries. Moreover, they report strong evidence that the linkage between fiscal and monetary policy has shifted post-1980, when fiscal and monetary policies became much more complementary. The main problem with this empirical literature literature is that without a structural model it is difficult to interpret the empirical correlations between the two policy variables. In the work of Mélitz (1997, 2000) and Wyplosz (1999) one cannot tell whether the correlation between the policy instruments over the cycle derives from systematic policy responses or from responses to structural or policy shocks. In the VARs estimated by Muscatelli et al. (2001) the focus is on the reaction of policy instruments to other policy shocks, but it is notoriously difficult to interpret implicit policy reaction functions in VARs especially if the 'true' underlying structural model is forward-looking. More recently, Muscatelli et al. (2003) examine the interaction of monetary and fiscal policies using an estimated New Keynesian dynamic general equilibrium model for the US. In contrast to earlier work they show that the strategic complementarity or substitutability of fiscal and monetary policy depends crucially on the types of shocks hitting the econ-

\footnotetext{
${ }^{3}$ The number of contributions applying VAR techniques is still limited. This may be due to the critique in Mountford and Uhlig (2002) that true fiscal policy surprises may be difficult to detect in a VAR model.
} 
omy, and on the assumptions made about the underlying structural model. The greater complementarity of fiscal and monetary policy seen in the 1990s compared to the 1980s was due to the changing nature of the underlying shocks.

Our focus in this paper is different. We estimate a N-K DSGE model which, in contrast to our earlier work and other attempts to estimate structural New Keynesian models ${ }^{4}$, allows for a richer range of transmission channels for fiscal policy, whilst still maintaining a model where the structural parameters are estimated using econometrics. This model is then used to conduct policy analysis to see how fiscal and monetary policy interact and what implications the degree of inertia in the structural model and in the policy rules has for monetary and fiscal policy design. The introduction of central bank independence in most of the industrialised economies has raised the issue of whether fiscal and monetary policies are properly co-ordinated. One motivation for this paper is to show that fiscal stabilizers, which can be shown to be counterproductive in standard DSGE models (e.g. Muscatelli et al., 2003) ${ }^{5}$ significantly improve welfare in an economy characterized by an important proportion of rule-of-thumb consumers. In particular, taxation rules based on automatic stabilisers can be shown to have a welfareenhancing effect. Our results are complementary to those obtained using different frameworks by other researchers. Gordon and Leeper (2003) find, using a calibrated model for the US economy, that fiscal stabilization policies tends to destabilize the business cycle because of their impact on debt service obligations. Jones (2002) uses an estimated stochastic growth model (without price stickiness) for the US to show that fiscal policy had limited stabilization effects in the post-war period.

\section{A N ew-K eynesian Structural Model}

We use a small forward-looking N-K DSGE model, comprising a dynamic IS model for output and a 'New Keynesian Phillips Curve' specification for

\footnotetext{
${ }^{4}$ See Gali et al. (2001), Leith and Malley (2002), Smets and Wouters (2002).

${ }^{5}$ In Muscatelli et al. (2003) our fiscal rules are estimated and we do not examine alternative forms for these rules. In that paper we show that countercyclical fiscal policy can be welfare-reducing if fiscal and monetary policy rules are inertial and not co-ordinated. Our conjecture in that paper was that this surprising result was probably due to the interaction of highly inertial estimated monetary and fiscal policy rules. In this paper we study fiscal policy rules in a DSGE model which involves a richer range of fiscal channels.
} 
inflation.

\subsection{Households}

We assume two types of households. Households in the first group, $i$, benefit from full access to the capital markets and are therefore free to optimize. The proportion of optimising consumers in the economy is given as $(1-\vartheta)$. Each optimizing consumer is assumed to maximize an intertemporal utility function given by:

$$
E_{t} \sum_{s=0}^{\infty} \beta^{s}\left(\frac{1}{1-\rho}\left(C_{t+s}^{o i} / H_{t+s}^{i}\right)^{1-\rho}-\frac{\varepsilon^{l}}{1+\varphi}\left(N_{t+s}^{o i}\right)^{1+\varphi}\right)
$$

where $C_{t}^{o}$ represents consumption of a basket of goods (to be defined below), $H_{t}$ is an index of external habits, $\rho$ is the coefficient of relative risk aversion, $N_{t}^{o}$ is the level of employment, and $\varepsilon^{l}$ is a shock to labour supply. Following Smets and Wouters (2002) we assume that habits depend on past aggregate consumption, $C^{T}$ :

$$
H_{t+s}^{i}=\left(C_{t+s-1}^{T}\right)^{\lambda}
$$

Optimizing consumers maximize (1) subject to their intertemporal budget constraint, which is expressed in real terms as:

$$
\left(1 / r_{t}\right) a_{t+1}^{i}=a_{t}-C_{t}^{o i}+\frac{W_{t}}{P_{t}} N_{t}^{o i}+D_{t}^{i}+\left(G_{t}^{T R i}-T_{t}^{i}\right)
$$

where consumers hold their financial wealth $\left(a_{t}\right)$ in the form of one-period state-contingent securities, which yield a return of $r_{t}$. The optimizing consumer's disposable income consists of labour income $w_{t} N_{t}^{o i}$ plus the dividends from the profits of the imperfectly competitive firms $D_{t}^{i}$, plus public transfers $G_{t}^{T R i}$ minus personal taxes $T_{t}^{i}$, lump-sum by assumption.

As in Galí et al. (2002) we assume that a proportion $\vartheta$ of households follow a rule of thumb, and consume out of current disposable income. This admittedly ad hoc assumption may be justified assuming myopia or limited participation to capital markets. We also assume that rule-of-thumb consumers supply a constant amount of labour ${ }^{6}, \overline{N^{R T}}$. Thus the consumption function of the representative rule-of-thumb consumer amounts to:

\footnotetext{
${ }^{6}$ Galì et al. (2003) show that supplying a constant amount of labour is optimal when net taxes, $\left(G_{t}^{T R}-T_{t}\right)$, levied on rule-of-thumb consumers are always nil. This result
} 


$$
C_{t}^{R T j}=\bar{N}^{R T} \frac{W_{t}}{P_{t}}+\left(G_{t}^{T R j}-T_{t}^{j}\right)
$$

\subsection{Firms}

Firms' production technology is assumed to be a simple Cobb-Douglas function of labour and capital for each consumption good variety $z$. Capital is assumed fixed and normalized to unity:

$$
Y_{t}(z)=A\left(N_{t}(z)\right)^{1-\alpha}
$$

We introduce fiscal distortions by assuming that taxes on labour take the form of a uniform payroll tax ${ }^{7}$. Therefore firms' demand for labour is defined as:

$$
(1-\alpha) A\left(N_{t}(z)\right)^{-\alpha}=\frac{W}{P}+t_{P R}^{*}
$$

where $t_{P R}^{*}$ is the tax rate per unit of employed labour, i.e. $t_{P R}^{*}=\frac{T^{*}}{N}$, where $T^{*}$ are the total revenues from the payroll tax.

Turning next to the model of firms' pricing behavior, we consider a standard model of monopolistic competition with sticky prices, as set out in Galí, Gertler and López-Salido (2001), and Leith and Malley $(2002)^{8}$. Total consumption is given by a standard CES function of imperfectly substitutable varieties of consumption goods $z$ :

$$
C_{t}^{i}=\left[\int_{0}^{1}\left(C_{t}^{i}(z)\right)^{\frac{\theta}{\theta-1}} d z\right]^{\frac{\theta}{\theta-1}}
$$

Given this, consumption of each variety of the consumption good is given by:

would never obtain in our model, where taxes and transfers are explicitly modeled. Thus, for sake of simplicity we assume a constant labour supply. Since consumption cannot be negative, this implies that we impose a lower bound on $\left(G_{t}^{T R}-T_{t}\right)$ for any given level of the real wage.

${ }^{7}$ This implies that the optimizing consumer's choice between leisure and consumption is not affected.

${ }^{8}$ See also Erceg, Henderson and Levin (2000), and Sbordone (2002). 


$$
C_{t}^{i}(z)=\left[\frac{P_{t}(z)}{P}\right]^{-\theta} C_{t}^{i}
$$

where $P_{t}(z)$ is the price of good $z$, and $P$ is the consumption price index given by the aggregator:

$$
P=\left[\int_{0}^{1}\left(P_{t}(z)\right)^{1-\theta} d z\right]^{\frac{1}{1-\theta}}
$$

Sticky prices are incorporated into this model, by assuming a Calvo pricing mechanism, with some proportion of firms adjusting their prices every period, and the rest supplying output on demand, at a constant price.

\subsection{The IS and the P hillips curve}

By log-linearizing the model around steady state we are then able to derive the forward-looking IS and the "New Keynesian Phillips curve (see the Appendix for a proof) ${ }^{9}$ :

$$
\widehat{y}_{t}=a_{1}\left\{\begin{array}{c}
a_{2}\left[a_{3} E_{t}\left\{\Delta \widehat{n}_{t+1}\right\}+a_{4} \Delta \widehat{t}_{t+1}^{*}\right]-a_{5} E_{t}\left\{\Delta\left(G_{t+1}^{T R}-T_{t+1}\right)\right\}+ \\
+a_{6} \frac{\bar{G}}{\bar{Y}} \widehat{g}_{t}+a_{7}\left[\widehat{y}_{t-1}-\frac{\bar{G}}{\bar{Y}}\left(\widehat{g}_{t-1}\right)\right]-\left(\frac{\overline{C^{o}}}{\bar{C}}\right)\left(\overline{\frac{C}{Y}} \frac{1}{\rho}\right) \widehat{r}_{t}+\widehat{y}_{t+1}-\frac{\bar{G}}{\bar{Y}} \widehat{g}_{t+1}
\end{array}\right\}
$$

where: $a_{1}=\left[1-\left(\frac{\overline{C^{o}}}{\bar{C}}\right)\left(\frac{1-\rho}{\rho}\right) \lambda\right]^{-1} ; a_{2}=\frac{\overline{N^{R T}}}{\bar{N}} \frac{\overline{N\left(\frac{W}{P}\right)}}{\bar{Y}}$;

$$
\begin{aligned}
& a_{3}=\left[\alpha-\frac{\overline{T^{*}}}{\bar{N}\left(\frac{\overline{\frac{W}{P}}}{\bar{P}} \overline{\frac{T^{*}}{N}}\right)}\right] \frac{\left(\frac{\bar{W}}{\bar{P}}+\frac{\overline{T^{*}}}{\bar{N}}\right)}{\left(\frac{W}{P}\right)} ; a_{4}=\frac{\overline{T^{*}}}{\overline{N\left(\frac{W}{P}\right)}} ; a_{5}=\vartheta\left(\frac{\overline{G^{T R}-T}}{\bar{Y}}\right) ; \\
& a_{6}=\left[1+\left(\frac{\overline{C^{o}}}{\bar{C}}\right)\left(\frac{\rho-1}{\rho}\right) \lambda\right] ; a_{7}=\left(\frac{\overline{C^{o}}}{\bar{C}}\right)\left(\frac{\rho-1}{\rho}\right) \lambda ; \\
& \overline{C^{o}}=1-\left(1-\frac{\bar{G}}{\bar{Y}}\right)^{-1}\left[\frac{\overline{N^{R T}}}{\bar{N}} \frac{\overline{N\left(\frac{W}{P}\right)}}{\bar{Y}}+\frac{\vartheta\left(\overline{G^{T R}-T}\right)}{\bar{Y}}\right]
\end{aligned}
$$

where $\widehat{g}_{t}$ is government spending excluding government transfers $\widehat{G^{T R}}$. 'Hatted' lower-case variables represent percentage deviations from the steady

\footnotetext{
${ }^{9}$ We ignore investment and the external sector. Arguably, the open-economy considerations are less important to the USA, which is the focus of our analysis here. The extension of our modeling approach to the open economy is left to further work.
} 
state. 'Barred' variables denote steady-state values. At first sight eq. (10) looks very complex. In fact, by imposing no habit, $\lambda=0$, and the absence of rule-of-thumb consumers, $\frac{\bar{N} \overline{N T}}{\bar{N}}=\vartheta=0$, eq. (10) would collapse to a cancellare(standard) purely forward looking IS curve. Note that consumption habit introduces a link between current and past output (as in Carroll, 2000, Leith and Malley, 2002; Smets and Wouters, 2002). Moreover, the presence of non-optimizing consumers establishes a link between the demand for goods, net personal taxes, $G^{T R}-T$, and the real wage. Fiscal policy impacts on output in three ways. First, through the usual resource withdrawal effect of government consumption, $\widehat{g}_{t}$; second, through the impact of net personal taxes $G^{T R}-T$ on the current disposable income of rule-of-thumb consumers. Third, through the impact of payroll taxes $T^{*}$ on the real wage of rule-of-thumb consumers ${ }^{10}$. Finally, rule-of-thumb consumers weaken the impact of interest rate policy on aggregate demand. As shown in Galì et al. (2003) this may have important implications for the conduct of monetary policy. indeed, our estimates confirm that rule-of-thumb consumers weaken the output response to interest rate changes.

It is important to note that whilst government spending impacts on the consumption behaviour of optimising consumers via the resource-withdrawal effect, taxation impacts through its effect on disposable income for ruleof-thumb consumers, and hence via the external habit (total consumption) variable. This ensures that government spending enters via a distributed lag in (10) which sum to zero, while personal and payroll taxes enter in differences, with coefficients of different size. As we shall see below, this drives some of the results of the model.

Turning to the Phillips curve, we define $(1-\xi)$ as the proportion of firms adjusting their prices every period. A share $\gamma$ of these is assumed to index prices to inflation in the previous period ${ }^{11}$, whereas the rest, $(1-\gamma)$, set their prices optimally to maximize expected discounted real profits ${ }^{12}$, with a discount factor $\beta$.

\footnotetext{
${ }^{10}$ From equations (4) and (6) it should be clear that, in each period, the equilibrium real wage is inversely related to employment and the payroll tax. In the Appendix we explain why the rate of change of these variables affects current output.

${ }^{11}$ This was pioneered by Galí and Gertler (1999). Similar backward-looking elements can be introduced to the NKPC equation by introducing indexation of all non-re-optimised prices (Christiano, Eichenbaum and Evans, 2001, and Woodford, 2002, chapter 3).

${ }^{12}$ A similar specification for the New Keynesian Phillips curve can be obtained by making the indexation process part of the optimisation process (see Smets and Wouters, 2002).
} 
The firms' optimization, together with the assumptions about Calvo pricing and indexation lead to an expression for price-setting which can be loglinearized to yield (see the Appendix for details):

$$
\widehat{\pi}_{t}=\frac{\gamma \widehat{\pi}_{t-1}+\beta \xi E_{t} \widehat{\pi}_{t+1}}{\xi+\gamma(1-\xi(1-\beta))}+\frac{(1-\gamma)(1-\xi)(1-\gamma \xi)}{[\xi+\gamma(1-\xi(1-\beta))][1+(\alpha /(1-\alpha)) \theta]} \widehat{s}_{t}
$$

where $\widehat{s}_{t}$ is the percentage change from steady state of the labour cost share, which is given ${ }^{13}$ by $\widehat{s}_{t}=\frac{\widehat{N\left(\frac{W}{P}\right)}}{\overline{N\left(\frac{W}{P}\right)}+\overline{T^{*}}}(\widehat{w-p})+\frac{\overline{T^{*}}}{\overline{N\left(\frac{W}{P}\right)}+\overline{T^{*}}}\left(\widehat{t^{*}}-\widehat{n}\right)+\widehat{n}_{t}-\widehat{y}_{t}$

Equations (10) and (11) constitute our structural model. It is important to note that in estimating (11), we treat real wages and employment as exogenous. Other recent contributions (Leith and Malley, 2002, Smets and Wouters, 2002) estimate wage equations, and adding a wage equation would have enabled us to consider the possibility of sticky wage dynamics. However, this would have also added to the complexity of the model. As discussed below, when simulating our model we make some allowance for wage adjustment.

\section{Empirical Results}

\subsection{Data and Scope of the Study}

We now turn to the empirical results ${ }^{14}$. We estimate the two equations (10) and (11), using US quarterly data, over the sample period 1970(1)-2001(2). The data definitions used are reported in the Data Appendix.

The data have been seasonally adjusted, and to capture the spirit of the NK models as log-linearizations, the data are transformed so that the vari-

\footnotetext{
${ }^{13}$ Galí, Gertler and López-Salido (2001) specify (10) in terms of average real marginal cost $(m c)$. Note that, in levels:

$$
s_{t}=\frac{(1-\alpha)}{m c_{t}}
$$

${ }^{14}$ The estimation was carried out using RATS, version 5.
} 
ables are expressed in deviations from the 'steady state' ${ }^{15}$. Real variables are de-trended ${ }^{16}$, whilst the series on inflation and the nominal interest rate (the federal funds rate) are demeaned. Note that as the inflation rate and interest rate always enter the model together, all the equations are 'balanced' in terms of the levels of integration of the dependent and explanatory variables. The government spending data $(G)$ is total government spending excluding transfers and interest payments, whilst we use employers' social security contributions as payroll taxes $\left(T^{*}\right)$, and government transfers minus personal taxes as $\left(G^{T R}-T\right)$.

\subsection{Estimation M ethods}

The New Keynesian model consists of equations that are non-linear in parameters. Following Hansen (1982) a model with rational expectations suggests some natural orthogonality restrictions that can be used in the generalized methods of moments (GMM) framework. We estimate (10), (11) using GMM. Each equation estimated using GMM is of the form:

$$
\mathbf{y}_{i t}=\mathbf{f}_{i}\left(\boldsymbol{\theta}_{i}, \mathbf{z}_{i t}\right)+\mathbf{u}_{i t}
$$

where for each equation $\mathrm{i}, \mathrm{y}_{i t}$ is the vector of dependent variables, $\boldsymbol{\theta}_{i}$ is the $\left(a_{i} \times 1\right)$ vector of unknown parameters to be estimated, and $\mathbf{z}_{i t}$ is the $\left(k_{i} \times 1\right)$ vector of explanatory variables. The GMM approach is based on the fact that $\widetilde{\boldsymbol{\theta}}_{i}$, the true value of $\boldsymbol{\theta}_{i}$, has the property $E\left[\mathrm{~h}_{i}\left(\widetilde{\boldsymbol{\theta}}_{i}, \mathbf{w}_{i t}\right)\right]=0$, where $\mathbf{W}_{i t} \equiv\left(\mathbf{y}_{i t}^{\prime}, \mathbf{Z}_{i t}^{\prime}, \mathbf{X}_{i t}^{\prime}\right)$, and $\mathbf{X}_{i t}$ is an $\left(r_{i} \times 1\right)$ vector of instruments that are correlated with $\mathbf{z}_{i t}$. GMM then chooses the estimate $\boldsymbol{\theta}_{i}$ so as to make the sample moment as close as possible to the population moment of zero. In our estimates we use four lags of the dependent variable and the exogenous variables as instruments. The validity of these instruments can be tested for each equation i using Hansen's J-test, which is distributed as a $\chi^{2}\left(r_{i}-a_{i}\right)$ statistic under the null of valid orthogonality conditions.

GMM or IV estimation has been used by a number of authors to estimate

\footnotetext{
${ }^{15}$ Which is commonplace in this literature (see Smets and Wouters, 2002, Leith and Malley, 2002).

${ }^{16}$ We experimented with both a Hodrick-Prescott filter and regression on a polynomial (cubic) trend for the real variables, and using CBO and OECD data on potential output. The results reported here use a HP trend $(\lambda=1600)$.
} 
NK models ${ }^{17}$. One problem is that the estimated IS and NKPC equations are highly nonlinear in parameters, and the rank condition for identification is not met unless a number of parameters in these two equations are fixed. We follow Galí, Gertler and López-Salido (2001) and Leith and Malley (2002) in imposing restrictions on some of the parameters. We fix $\theta=4$, implying a price-mark-up ${ }^{18}$ of $30 \%, 1-\alpha=0.6$ and that ${ }^{19}$ the habit formation parameter on aggregate consumption is unity $(\lambda=1)$. In the NKPC equation, we use the average sample values for the steady-state ratios $\left(\overline{N\left(\frac{W}{P}\right)} \overline{/ N\left(\frac{W}{P}\right)}+\right.$ $\left.\overline{T^{*}}\right)=0.805$ and $\left(\overline{T^{*}} / \overline{N\left(\frac{W}{P}\right)}+\overline{T^{*}}\right)=0.095$. Moreover, in the IS equation we impose that the following steady-state values are given by their average values over our sample ${ }^{20}$, i.e. $(\bar{C} / \bar{Y})=0.83,(\bar{G} / \bar{Y})=0.17, \overline{T^{*}} / \overline{N\left(\frac{W}{P}\right)}=$ $0.105,\left(\overline{G^{T R}-T} / \bar{Y}\right)=-0.177$. In addition, we impose the restriction $\frac{\overline{C^{o}}}{\bar{C}}=$ $1-\left(1-\frac{\bar{G}}{\bar{Y}}\right)^{-1}\left[\frac{\overline{N^{R T}}}{\bar{N}} \frac{\overline{N\left(\frac{W}{P}\right)}}{\bar{Y}}+\frac{\vartheta\left(\overline{G^{T R}-T}\right)}{\bar{Y}}\right]$ suggested by the theory in the IS equation (see the derivation in the Appendix).

However, it is worth noting that even with these restrictions, because of the absence of any cross-equation restrictions ${ }^{21}$, the structural parameters estimates are poorly defined. Therefore, as we note below, we had to impose additional restrictions and to use a grid-search procedure in order to obtain parameter estimates that were statistically well-defined.

\footnotetext{
${ }^{17}$ For instance, Galì, Gertler and Lopez-Salido (2001), Leith and Malley (2002), Kara and Nelson (2002), Muscatelli et al. (2003).

${ }^{18}$ This follows Erceg, Henderson and Levin (2000). It is a lower value of the elasticity of substitution than that used by Galí, Gertler and López-Salido (2001) and Leith and Malley (2002), but in practice the estimates of the other parameters did not seem to be very sensitive to changes in the value of $\theta$. However, a higher mark-up does seem to be more sensible given that marginal costs exclude capital costs in this framework. In addition, a higher value of $\theta$ would imply an implausibly small direct effect of output on prices through the marginal cost term.

${ }^{19}$ In our earlier study, Muscatelli et al. (2003), where we estimate $\lambda$ freely in a simpler version of the IS curve we found that it was insignificantly different from unity.

${ }^{20}$ Note that $\left(\frac{\bar{W}}{\bar{P}}+\frac{\overline{T^{*}}}{\bar{N}}\right) /\left(\frac{W}{P}\right)=1+\overline{T^{*}} / \overline{N\left(\frac{W}{P}\right)}=1.105$. Furthermore, $\overline{N\left(\frac{W}{P}\right)} / \bar{Y}$ is simply equal to the labour share in equilibrium, which we set equal to $(1-\alpha)=0.6$.

${ }^{21}$ Unlike Leith and Malley (2002) the discount factor $\beta$ does not enter our IS equation as our habit formation is based on external habits ('keeping up with the Joneses'). See also Carroll (2000) and Campbell and Cochrane (1999).
} 


\subsection{Model Estimates}

Table 1 reports the estimated New Keynesian model using GMM over the full sample period. In estimating the NK output equation, we use the ex ante real interest rate $\left(\widehat{r}_{t}=\widehat{i}_{t}-E_{t} \widehat{\pi}_{t+1}\right)$, where $\widehat{i}_{t}$ is the federal funds rate. As noted above, we found that the parameter estimates were relatively imprecise, even after imposing the restriction suggested by theory that $\left(\beta, \gamma, \xi, \overline{N^{R T}} / \bar{N}\right)$ should all be less than unity. For the NKPC equation we conducted a grid search to minimise the standard error of the estimate, and fixed the discount factor $\beta$ at 0.99 , a value consistent with that used by Smets and Wouters (2002), but larger than that estimated by Galí, Gertler and López-Salido (2001), Leith and Malley (2002) and Muscatelli et al. (2003). This improved the precision of the other parameter estimates. For the output equation, we estimated the model in two stages. Note from (10) that if one estimates this equation without imposing any restrictions on the parameters, by dividing the coefficient on $\widehat{y}_{t-1}$ by the coefficient on $\widehat{y}_{t+1}$ one obtains an estimate of $\left(\frac{\overline{C^{o}}}{\bar{C}}\right)\left(\frac{1-\rho}{\rho}\right)$, where $\lambda$ is been fixed at unity. Note also that by dividing the estimated coefficient on $\widehat{r}_{t}$ by the estimated coefficient on $\widehat{y}_{t+1}$ one obtains an estimate of $\left(\frac{\overline{C^{o}}}{\bar{C}}\right)\left(\frac{\bar{C}}{\bar{Y}} \frac{1}{\rho}\right)$, where again recall that $\frac{\bar{C}}{\bar{Y}}$ is fixed at its sample average value. This allows us to obtain a point estimate for $\rho$ and for $\left(\frac{\overline{C^{o}}}{\bar{C}}\right)$, which are 3.18 and 0.839 respectively. We can also compute asymptotic standard errors for these two parameters. We re-estimate (10) having fixed the values of $\rho$ and for $\left(\frac{\overline{C^{o}}}{\bar{C}}\right)$ from the first stage of the estimation to find estimates for $\frac{\overline{N^{R T}}}{\bar{N}}$ and $\vartheta$. This improved the precision of the estimates for the latter parameters.

The overall fit for the two equations is good. The $R^{2}$ statistic for (10) is 0.92 and for (11) is 0.98. The Hansen test for the two equations are respectively 39.2 and 35.4 , which are distributed as a $\chi^{2}(27)$ statistic under the null of valid instruments. The null hypothesis of valid instruments is not rejected at the $5 \%$ significance level.

Our point estimates suggest that about $37 \%$ of consumers are rule-ofthumb consumers, whilst $84 \%$ of total consumption in steady state is given by optimising consumers. Rule-of-thumb consumers account for about $59 \%$ of total employment. Our estimates of the Calvo parameter suggest that about $57 \%$ adjust their prices every period, which is a slightly higher proportion than that estimated by Galí et al. (2001) and Muscatelli et al. (2003). Of 
these, about half simply index prices.

Table 1: Model Estimates

\begin{tabular}{|l|l|}
\hline Parameter & Estimate \\
\hline$\lambda$ & $\begin{array}{l}1.00 \\
(-)\end{array}$ \\
\hline$\rho$ & $\begin{array}{l}3.18 \\
(1.27)\end{array}$ \\
\hline$\vartheta$ & $\begin{array}{l}0.366 \\
(0.097)\end{array}$ \\
\hline$\overline{N^{R T}}$ & $\begin{array}{l}0.586 \\
(0.155)\end{array}$ \\
\hline $\bar{N}$ & $\begin{array}{l}0.839 \\
(0.258)\end{array}$ \\
\hline $\bar{C}$ & $\begin{array}{l}0.99 \\
(-)\end{array}$ \\
\hline$\beta$ & $\begin{array}{l}0.433 \\
(0.103)\end{array}$ \\
\hline$\xi$ & $\begin{array}{l}0.492 \\
(0.111)\end{array}$ \\
\hline$\gamma$ &
\end{tabular}

\subsection{Dynamic and Stochastic Simulations}

Having estimated our structural model, we now perform a number of dynamic simulation experiments to investigate the properties of this simple NK model $^{22}$, and the transmission of fiscal and monetary policies.

We focus on the dynamic model solution, shocking each structural equation and policy equation in turn, to simulate the effects of a structural or policy variable shock on the other endogenous variables in the model. This allows us to examine the properties of the model, and the response of output and inflation to policy and structural shocks. Essentially this involves simulating the model without any reference to actual data. The variables treated as independent in the estimated model i.e. government transfers $\left(G_{t+1}^{T R}\right)$, the

\footnotetext{
${ }^{22}$ The model is solved using Winsolve version 3.0 (see Pierse, 2000), which provides numerical solutions for linear and non-linear rational expectations models. We solve our model using the Stacked Newton method in Winsolve. In solving the models with structural shocks (and further below with policy shocks) these are treated as unanticipated by economic agents.
} 
real wage $\left(\widehat{w-} p_{t}\right)$ and employment $\left(\widehat{n}_{t}\right)$, are simulated as follows: government transfers are simply assumed to be constant. On the other hand we do wish to endogenize the real wage and employment. In our simulations, we assume limited wage stickiness by postulating that nominal wages are indexed to inflation with a one-period $\operatorname{lag}^{23}$, whilst employment is determined by a log-linearization of the short-run production technology (5). To simulate the model, we close it by adding a Taylor rule for the federal funds rate. In order to provide a baseline for an analysis of inertial rules below, we assume a very simple type of forward-looking non-inertial Taylor rule:

$$
\widehat{i_{t}}=1.5\left(E_{t} \widehat{\pi}_{t+1}\right)+0.5\left(\widehat{y}_{t}\right)
$$

Excluding inertia from this Taylor rule has the advantage of allowing us to focus on the simulation properties of the structural model. As we shall see below (Section 5.1.1), an inertial monetary policy rule implies a considerable period of monetary expansion following an inflation increase. Excluding inertia allows us to focus on the structural properties of the fiscal channels in the model rather than on its performance when monetary policy is very inertial. The results of the dynamic model solution are shown in Figures 1-5. These display the responses of output, inflation and the real interest rate, following a temporary $1 \%$ shock to, respectively, the output, inflation, and nominal interest rate (the federal funds rate) equation, and to government spending and taxation. In the case of taxation we assume that there is a proportionate shock to both payroll and personal taxes. The initial shock is $1 \%$ and this then recedes with a 0.5 autoregressive parameter, and is set to zero after 4 quarters. Note that the government spending shock produces a positive impact on output (see Galí et al., 2002). As we shall see below, this result is not altered by the introduction of feedback rules for fiscal policy. It is interesting that by estimating a NK model with rule-of-thumb consumers we obtain estimated parameters which support Galí et al.'s (2002) conjecture that non-optimising consumers can explain the positive correlation between government spending shocks and output. Turning to taxation, as expected a temporary taxation shock tends to reduce output through its impact on IS, and increases inflation through the taxation wedge. As an illustration of the

\footnotetext{
${ }^{23}$ The absence of a wage-setting equation is less problematic than might seem at first sight. If one looks at US data from the 1990s, one can see that real wages and employment were far less volatile around their trend during the 1990s. Thus the assumption that wages simply respond to lagged inflation is not a major departure from reality.
} 
Output Shock

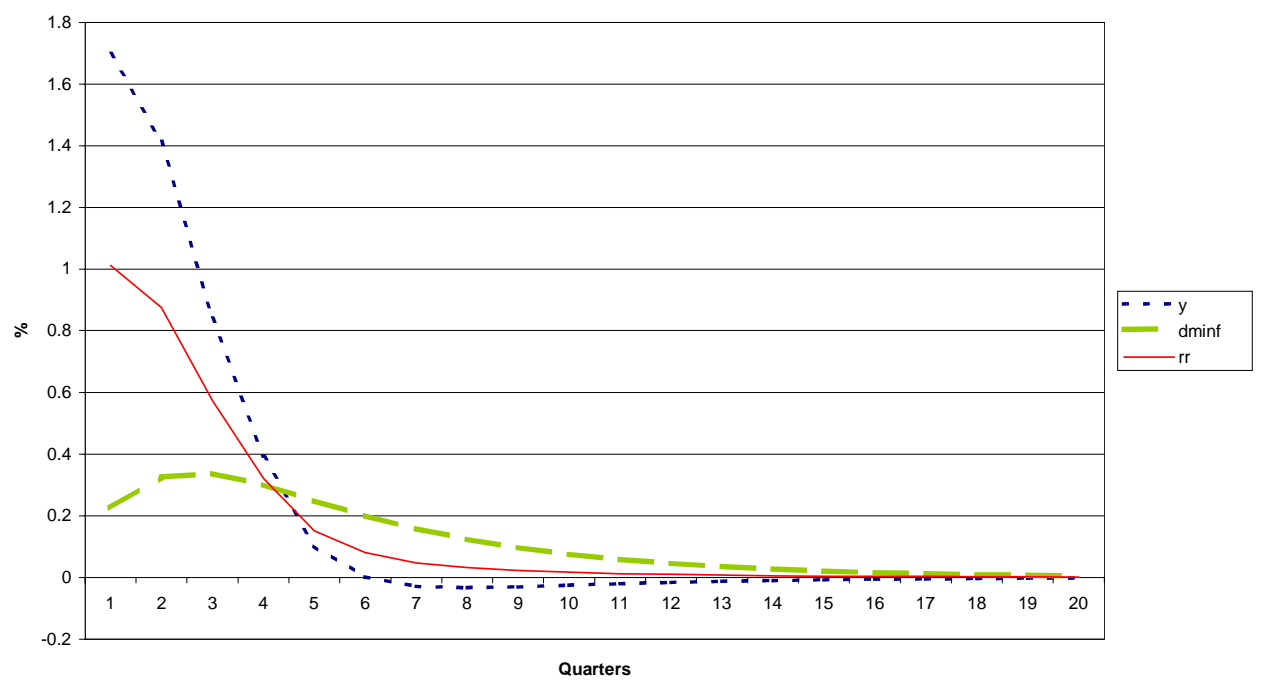

Figure 1: Output Shock

impact of the greater inertia caused by rule-of-thumb consumers, in the limit as the proportion of rule of thumb consumers fall to zero, the output increase following an output shock is about $25 \%$ smaller, and the system converges to steady state in about 6 quarters. 


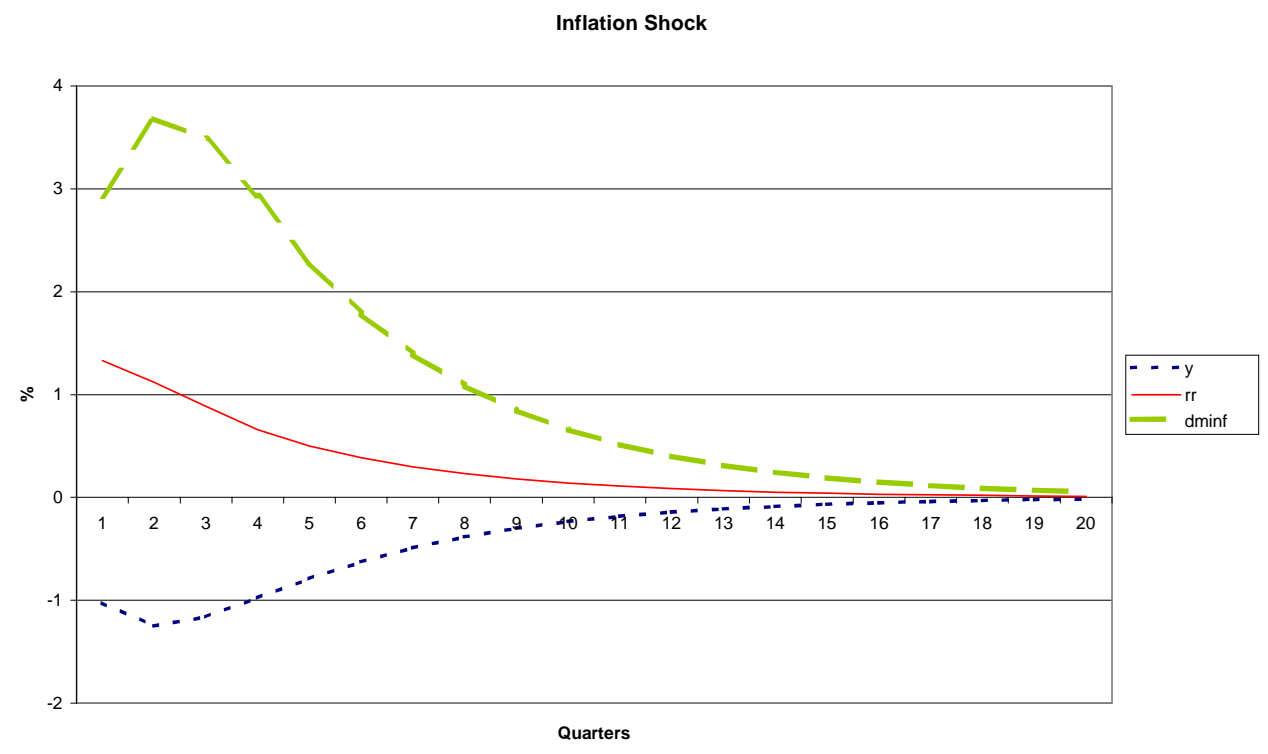

Figure 2: Inflation Shock

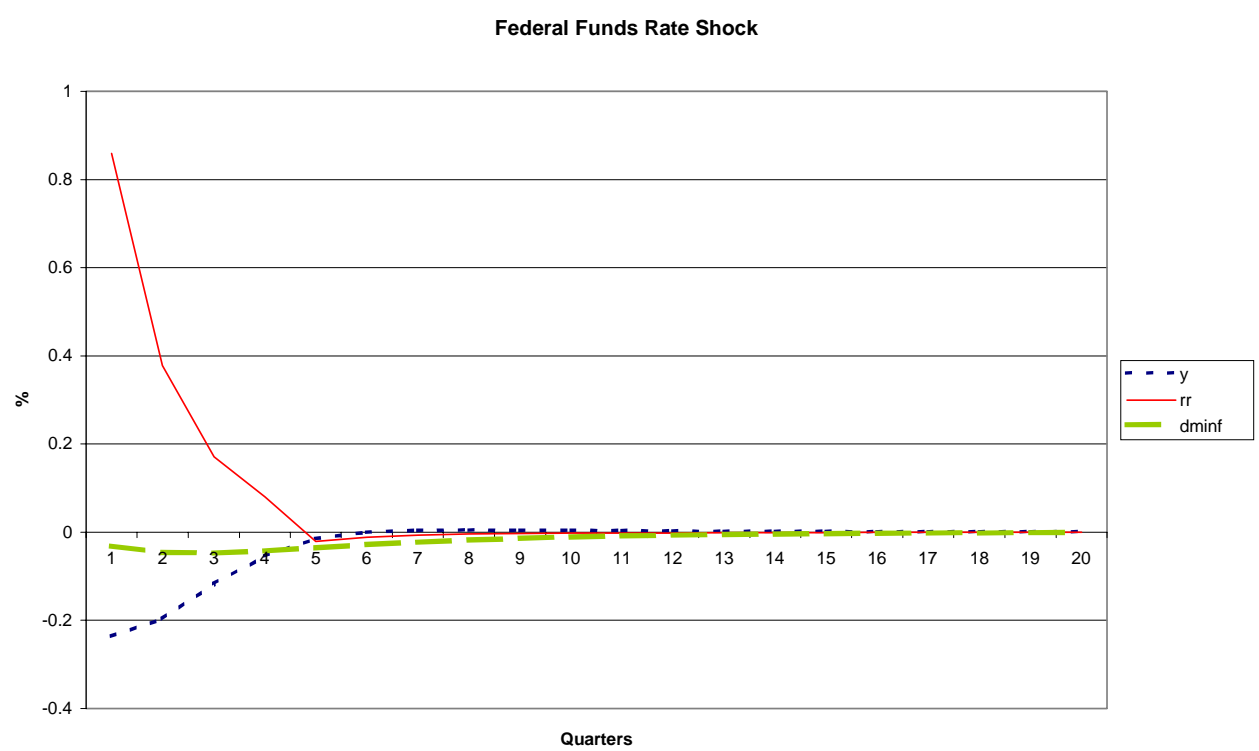

Figure 3: Fed Funds Rate Shock 


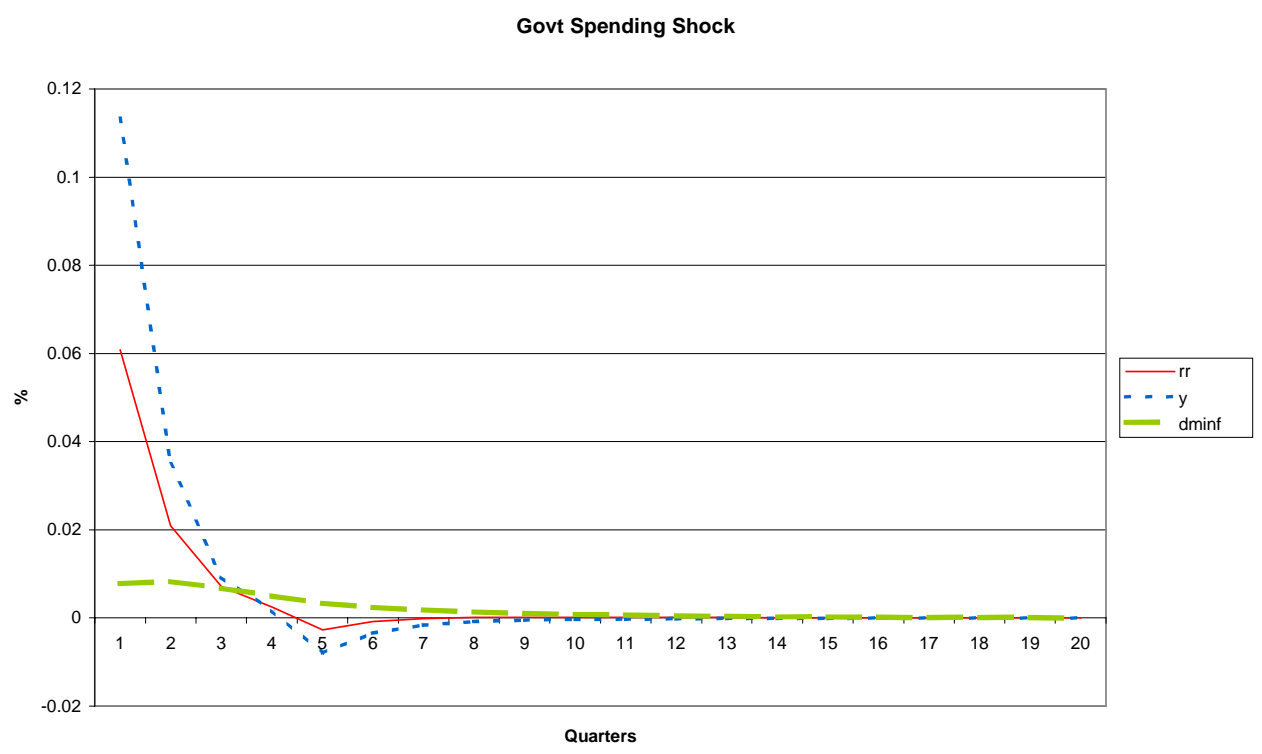

Figure 4: Govt Spending Shock

Taxation Shock

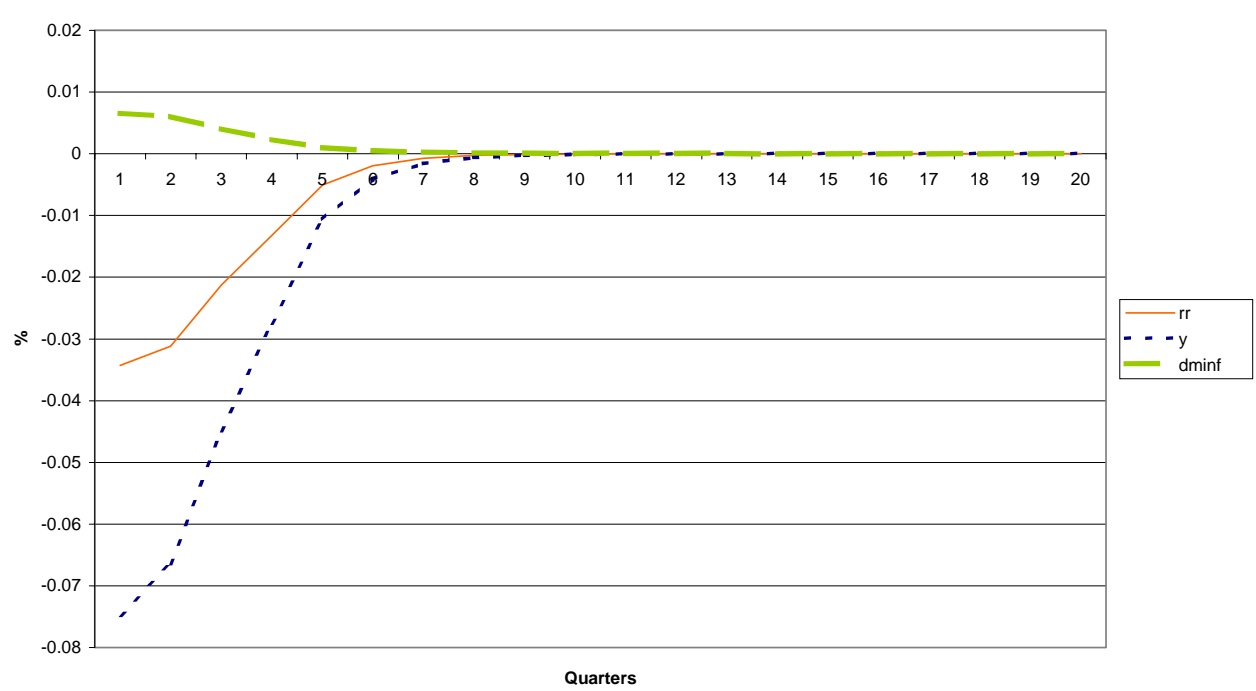

Figure 5: Taxation Shock 


\section{M onetary and F iscal Policy Interactions and Policy Design}

\subsection{Monetary and Fiscal Rules}

Having examined the dynamic properties of our estimated model, we now turn to the issue of policy design. As noted above, the earlier literature on monetary-fiscal interactions focused exclusively on understanding whether monetary and fiscal policies have tended to act together over the cycle. A more important issue is whether fiscal policies, and in particular the automatic stabilizers considered here, actually assist or impede the efforts of an independent central bank which adopts a forward-looking inflation targeting rule. More precisely, how should automatic stabilizers be designed in order to ensure that monetary and fiscal policy act in concert, i.e. as strategic complements?

In an earlier paper, Muscatelli et al. (2003), we presented evidence that estimated fiscal policy rules for the US appeared to be welfare-reducing, which seemed to accord with the evidence (using different modeling approaches) in Gordon and Leeper (2003) and Jones (2002). From the point of view of a central bank adopting an optimal policy rule designed to minimize a standard quadratic loss function in deviations of output, inflation and changes in the policy instrument (the interest rate). We are now able to re-examine the issue in a model where fiscal policy may play a more important role because rule-of-thumb consumers only indirectly react to the interest rate rule ${ }^{24}$. Furthermore, the current model considers some additional additional channels of transmission of fiscal policy: taxation effects on consumption through liquidity constrained consumers, and taxation wedge effects on inflation, as well as interaction effects due to the presence of rule-of-thumb consumers. In addition, instead of focusing on estimated fiscal rules ${ }^{25}$, we will consider a more systematic analysis of different rules for fiscal stabilizers.

\footnotetext{
${ }^{24}$ As shown in Galì et al. (2003), R-O-T consumers are affected by interest rate changes only to the extent that the real wage adjusts following the new labour conditions determined by the optimising consumers' reaction to such interest rate changes

${ }^{25}$ There is considerable evidence that estimated fiscal rules are not very stable because of the existence of different fiscal regimes. Favero and Monacelli (2003) identify a number of Ricardian and non-Ricardian fiscal regimes for the USA.
} 


\subsubsection{Monetary Rule}

Before turning to the issue of how one might design robust fiscal rules, let us turn first to monetary policy. Unlike fiscal policy rules, we have a better idea of how monetary policy has behaved in recent times, especially in the case of the US, where the institutional framework has not changed markedly for the Fed. There have been a number of attempts to estimate forward-looking interest rate rules for the US, following the seminal work of Clarida et al. (1998). Although there might be some concern that monetary policy rules have shown some instability over time ${ }^{26}$, Clarida, Galí and Gertler (1998, 2000) highlight only one particular shift in the Fed's monetary policy rule around the early 1980s, during the Volcker chairmanship of the Fed.

In order to simulate monetary-fiscal policy interactions, we estimate a forward-looking monetary policy rule for the sample period 1982(1)-2001(2). Our estimated monetary rule for the nominal interest rate $\widehat{i_{t}}$ follows a form similar to the standard forward-looking Taylor rule specification which has become commonplace in the literature ${ }^{27}$ (see Clarida, Galí and Gertler, 1998, 2000; Muscatelli et al. 2002; Giannoni and Woodford, 2002a,b),

$$
\widehat{i_{t}}=\phi_{1} E_{t} \widehat{\pi}_{t+q}+\phi_{2} \widehat{y}_{t+s}+\phi_{3} \widehat{i}_{t-1}
$$

where the rule also allows for interest-rate smoothing (inertia) if $\phi_{3} \neq 0$. In general we find that the best fit for this model is found for the specific case where $q=1, s=0^{28}$.

$$
\begin{array}{cccc}
\text { Table 2: Estimated } & \multicolumn{3}{c}{\text { M onetary }} \\
\text { Parameter } & \phi_{1} & \phi_{2} & \phi_{3} \\
& 0.209 & 0.148 & 0.885 \\
& (0.086) & (0.055) & (0.041)
\end{array}
$$

\footnotetext{
${ }^{26}$ Muscatelli, Trecroci and Tirelli (2002) provide some evidence that shifts may have occurred even after the Volcker years. One other caveat is that estimated monetary policy rules tend to misinterpret important discretionary policy shifts as unanticipated deviations from the policy rule.

${ }^{27}$ The main difference is that we use a contemporaneous value of the output gap (see Muscatelli et al. 2002) as opposed to expected future values, as in Clarida, Gali and Gertler (1998, 2000). For a detailed discussion of these issues, see Giannoni and Woodford (2002a,b). For an alternative approach to modeling interest rate responses, involving nonlinearities in reaction functions, see Cukierman and Muscatelli (2001).

${ }^{28}$ See Giannoni and Woodford (2002b) for a justification of why a short inflation-forecast horizon might be optimal in cases where the degree of 'rule of thumb' indexation $(\gamma)$ or inflation inertia is high.
} 
The estimated parameters for (14) are reported in Table 2. The Hansen test statistic is 24.73 , which is insignificant at the $5 \%$ level. The estimated equation shows a significant output gap effect on interest rates, and a longrun effect of expected inflation on nominal interest rates which is given by $\phi_{4}=\left(\phi_{1} /\left(1-\phi_{3}\right)\right)$, and which is significantly greater than unity $\left(\phi_{4}=1.817\right.$ with an asymptotic standard error equal to 0.095$)$.

This estimated monetary policy rule provides us with a benchmark against which to assess the performance of different designs for automatic fiscal stabilizers in our structural model.

\subsubsection{Fiscal Rules}

We consider a simple backward-looking format for our fiscal policy rules (automatic stabilizers), following inter alia Van Den Noord (2000), Westaway (2003) and Andres and Domenech (2003). This captures the more realistic lagged response of fiscal policy to macroeconomic variables due to automatic stabilizers:

$$
\begin{gathered}
\widehat{g}_{t}=\delta_{1} \widehat{g}_{t-1}-\delta_{2} \widehat{y}_{t-1} \\
\widehat{\tau}_{t}=\varphi_{1} \widehat{\tau}_{t-1}+\varphi_{2} \widehat{y}_{t-1}
\end{gathered}
$$

where $\widehat{\tau}_{t}$ is the vector of our two tax measures, personal taxes $\widehat{t}_{t}$ and payroll taxes, $\widehat{t}^{*}$. Our taxation rule therefore imposes the same adjustment pattern on both taxes, and does not look at how a mix of tax measures might improve the design of policy ${ }^{29}$. The importance of the taxation policy mix is considered further below. Note that we do not allow for any feedback of policy to budget deficits or debt accumulation ${ }^{30}$. Recall that our models

\footnotetext{
${ }^{29}$ Andres and Domenech (2003) provide an analysis of how different tax measures might impact on output and inflation variability.

${ }^{30}$ See for instance Bohn (1988) and Taylor (2000a,b). The lack of a debt or deficit stabilization term raises the issue of whether our fiscal rules imply a sustainable path for government debt. Given that we are not conducting historical simulations with our estimated models this not a problem, especially for small structural shocks. Obviously where one wishes to conduct historical or counterfactual simulations (see Muscatelli et al. 2003), then one would need to check whether the implied path for government debt is sustainable, and closely tracks that observed during the historical period analyzed. In this paper we will focus instead on dynamic simulations following small shocks and the issue of debt sustainability is less relevant, providing that we are considering sufficiently small
} 
are estimated using detrended data and focus on stabilization over the cycle rather than the shifts in fiscal regimes which often accompany the correction of deficits, or debt-correction strategies. Our fiscal rules are largely capturing automatic stabilizers through the autoregressive and the output gap terms.

For our baseline case, we set $\delta_{1}=\varphi_{1}=0.6, \delta_{2}=\varphi_{2}=0.5$. A coefficient of 0.5 on output is consistent with the empirical evidence in Van Den Noord (2000) and adopted in studies on fiscal stabilization (e.g. Westaway, 2003), and are broadly consistent with the correlations for US fiscal data over the cycle (cf. Gordon and Leeper, 2003). We allow for an element of inertia as empirical estimates of fiscal policy rules suggest an important role for an autoregressive term. We then consider a number of variants for the fiscal rules, and we also conduct some sensitivity analysis, to see to what extent the performance of these fiscal rules is affected by small changes in the estimated model parameters.

\subsection{Government spending rules versus Taxation Rules}

We now perform some dynamic simulation with our model, closing it by adding the estimated monetary policy rule and the taxation and government spending rules in (16) and (15). Rather than assuming a particular form of welfare loss function, in what follows we consider how the introduction of a fiscal policy rule impacts on output and inflation variability (variance frontiers) when it is combined with a monetary policy rule such as (14). Conducting welfare analysis with a NK model such as ours is complex, because of the presence of heterogeneous consumers (optimisers and rule-of-thumb consumers $)^{31}$, but computing variance frontiers allows a certain ranking of policy rules, where it is apparent that one rule dominates the other in terms of reducing both output and inflation variability.

To construct the variance frontiers we apply a monetary policy rule where the parameters $\phi_{2}$ and $\phi_{3}$ have the same values as those estimated and reported in Table 2 , but where we allow $\phi_{1}$ to vary ${ }^{32}$. We then compute the

shocks. Our fiscal rules are close in spirit to those of Taylor $(2000 \mathrm{a}, \mathrm{b})$, who finds that countercyclical fiscal policy is almost entirely characterized by the working of automatic stabilizers.

${ }^{31}$ See for instance Benigno and Woodford (2003). We are currently considering the extension of our modeling framework to include some welfare analysis.

${ }^{32}$ The variance frontiers are plotted for values of $\phi_{1}$ which vary between between 0.2 and 1.5. The reason for focusing on higher values of $\phi_{1}$ compared to the estimated value 


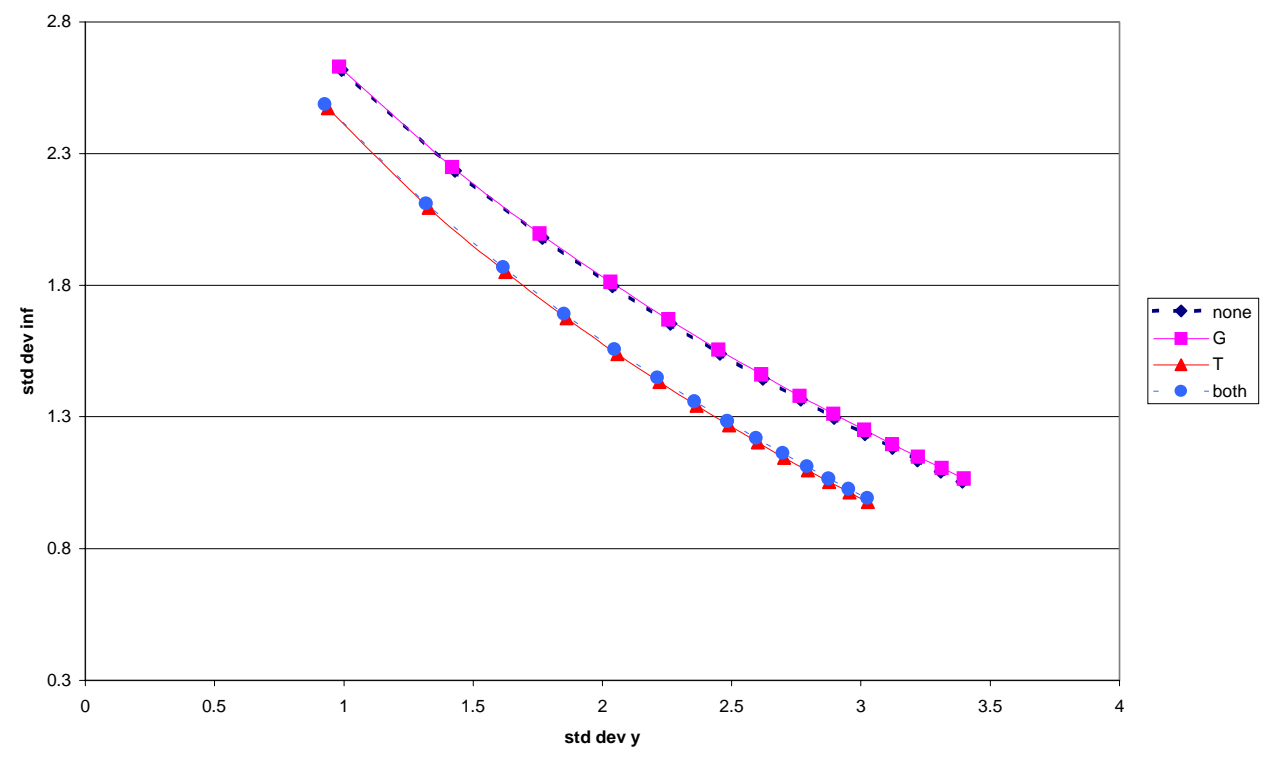

Figure 6: Variance Frontiers and Monetary-Fiscal Interactions

standard deviation of output and inflation in dynamic simulations following a shock to the Phillips Curve, and report these 'variance frontiers' in the figures which follow. The results shown below do not seem to be too sensitive to small changes in the values of the model parameters, in the sense of reversing the rank of the various policy rules, and we shall return to this point below. Figure 6 shows the variance frontiers when the model is simulated following a temporary $1 \%$ inflation shock, combining the forward-looking monetary policy rule with the fiscal policy rules in four scenarios:

(i) where fiscal policy is kept exogenously fixed, i.e. the automatic stabilizers (15) (16) are kept switched off (labelled 'none')

(ii) where only the government spending rule is switched on

(iii) where only the taxation feedback rule is switched on

(iv) where both rules are switched on (labelled 'both')

is that it is often argued that estimated monetary policy rules tend to underestimate the response of the central bank to shifts in expected inflation (and conversely overestimate the degree of inertia) because central banks do not continuously change their monetary stance. 
There are three points to note about these results. The first is that, in contrast with Muscatelli et al. (2003), automatic stabilizers are no longer welfare-reducing. In particular, countercyclical taxation policy seems able to reduce the variance of both output and inflation. The second point to note is that government spending does not have an unambiguous welfare-enhancing effect: introducing a feedback rule for government spending tends to shift the variance frontier very slightly north-westwards, lowering the variability of output, but at the expense of more variable inflation. This might explain our earlier results on the welfare-reducing properties of fiscal policies. Third, introducing both automatic stabilizers is still preferable to having none, even though the variance frontier shifts north-westwards, suggesting that taxation has a much greater impact on the variance frontier than government spending.

The explanation for this result lies in the different way in which government spending and taxation operates in the model: government spending varies the profile of output but its impact is ultimately reversed, as the distributed lag effect sums to zero. In contrast, taxation has an impact through both the wedge (a level effect) and through the IS curve (in difference terms), and this is not reversed because of its impact on external habits.

To investigate the relative importance of personal taxes relative to payroll taxes in stabilizing output and inflation, we repeated the above experiment using only personal taxes and then using only payroll taxes. In general we found that most of the stabilization effect comes from payroll taxes through their impact on the wedge, especially for cases where $\phi_{1}$ is high. The intuition for this is straightforward: following an adverse shock to the Phillips curve, output falls and as payroll taxes fall, they stabilise both inflation (through the wedge effect) and output (through the disposable income of rule-of-thumb consumers). In contrast personal taxes act only through the IS curve and hence stabilise output at the expense of inflation stability. Only where $\phi_{1}$ is low, so that the monetary authority reacts less forcefully to the inflation shock, do personal taxes help to stabilise output and inflation. In other words, payroll taxes are generally more complementary to monetary policy in this model.

\subsection{Inertial Fiscal Rules}

We now turn to the issue of how such automatic stabilizers should be designed. Would it be best for fiscal policy rules such as (15) and (16) to be 


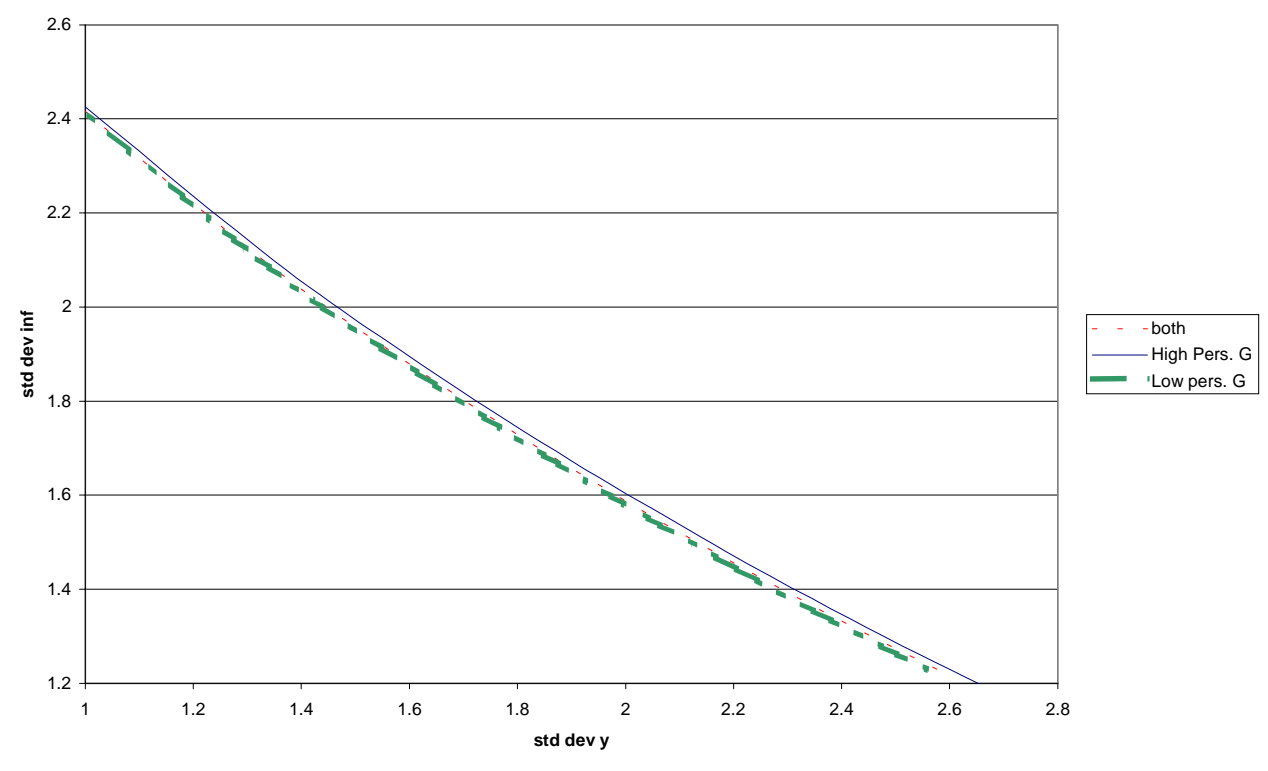

Figure 7: Inertia and Government Spending Rule

persistent? The literature on the design of monetary policy rules (see Giannoni and Woodford, 2002a,b) shows that inertial monetary policy rules can, in some circumstances be very beneficial. However, in our earlier paper (Muscatelli et al., 2003), our conjecture was that a lack of co-ordination between the two policies, especially when both are highly inertial, might cause a reduction in welfare.

In Figure 7 we show the effect on the variance frontier of changing the parameter $\delta_{1}$ to 0.9 (high persistence) and to 0.1 (low persistence), whilst keeping the taxation rule unchanged. In Figure 8, we similarly plot the variance frontiers when we vary $\varphi_{1}$ to 0.9 (high persistence) and 0.1 (low persistence).

Figure 7 in part confirms the conjecture in Muscatelli et al. (2003) about how inertia in government spending, when combined with a highly inertial monetary policy rule might be welfare-reducing. Although the variance frontier does not shift markedly, it is almost entirely encompassed by the standard case where $\delta_{1}=\varphi_{1}=0.6$ (labelled 'both'). Conversely, lowering the persistence of government spending produces a variance frontier which roughly overlaps that of the benchmark case. 


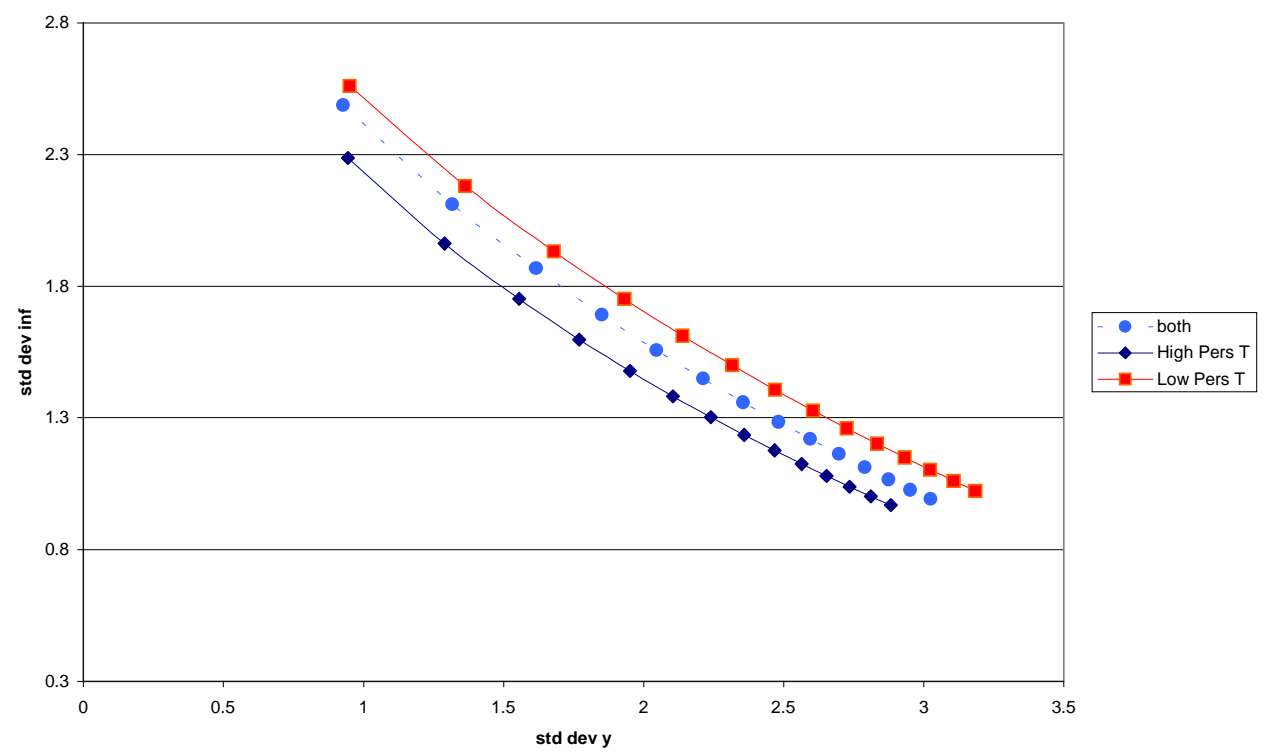

Figure 8: Inertia and Taxation Rule

Figure 8, however, shows that for taxation a high-persistence policy reduces both output and inflation variability and is closer to being optimal, given this particular monetary policy rule. By contrast a more countercyclical and less inertial taxation rule tends to raise the variability of both output and inflation. The intuition behind this result lies in the way in which (personal and payroll) taxation enters the IS curve, in difference form. A highly inertial taxation rule approximates an integral control rule, which is particularly efficient in the case where the output gap depends on the change in taxation. By decomposing the effect of payroll and personal taxes one can again show, as discussed above, that payroll taxes are a more effective complement to monetary policy.

\subsection{The Impact of Rule-of-Thumb Consumers}

How robust are our conclusions on the efficiency of automatic stabilizers to changes in the number of rule-of-rhumb consumers? Galí et al. (2002) find that increasing the proportion of rule-of-thumb consumers in a New Keynesian model with sticky prices can increase instability in the model and 


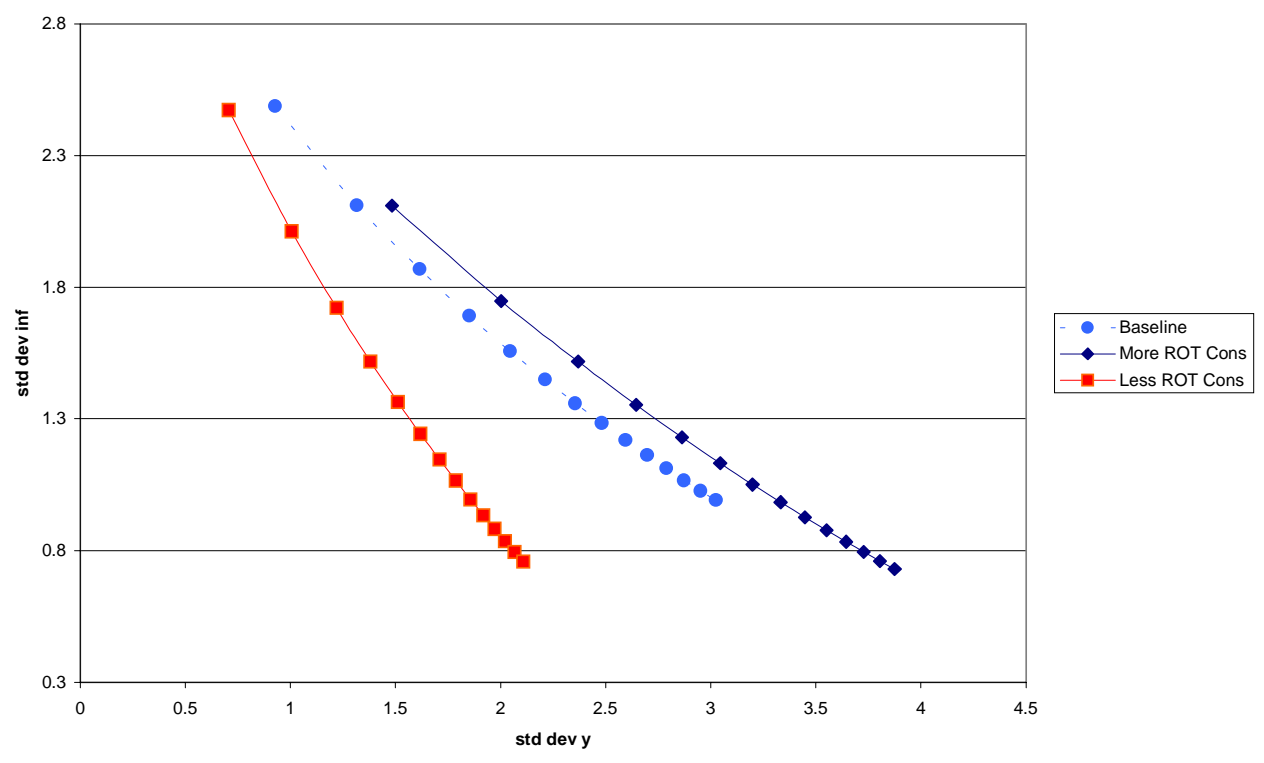

Figure 9: Varying the Proportion of Rule-of-Thumb Consumers: Impact of Fiscal Rules

potentially lead to indeterminacy.

In what follows we show the impact of raising the proportion of employment made up by rule-of-thumb consumers $\left(\overline{N^{R T}} / \bar{N}\right)$ to 0.7 (the 'More ROT Consumers' case), and consequently lowering the proportion of consumption determined by optimising consumers $\left(\overline{C^{\circ}} / \bar{C}\right)$ to 0.571 , or lowering the number of rule-of-rhumb consumers (the 'Less ROT Consumers' case), given by a value of $\left(\overline{N^{R T}} / \bar{N}\right)$ equal to 0.275 and a value of $\left(\overline{C^{\circ}} / \bar{C}\right)$ equal to 0.88 .

We again simulate the model following an inflation shock, and as shown in Figure 9, we see that a lower proportion of rule-of-thumb consumers tends to stabilise the model. It is important to note that there are two effects at play here. First, decreasing the number of rule-of-thumb consumers makes payroll taxes less effective. Second, it improves the degree of consumption smoothing, and raises the efectiveness of monetary policy by increasing the term on the interest rate in the IS curve. Clearly this second effect dominates, and causes the variance function to shift towards the origin, albeit by increasing the variability of inflation. 


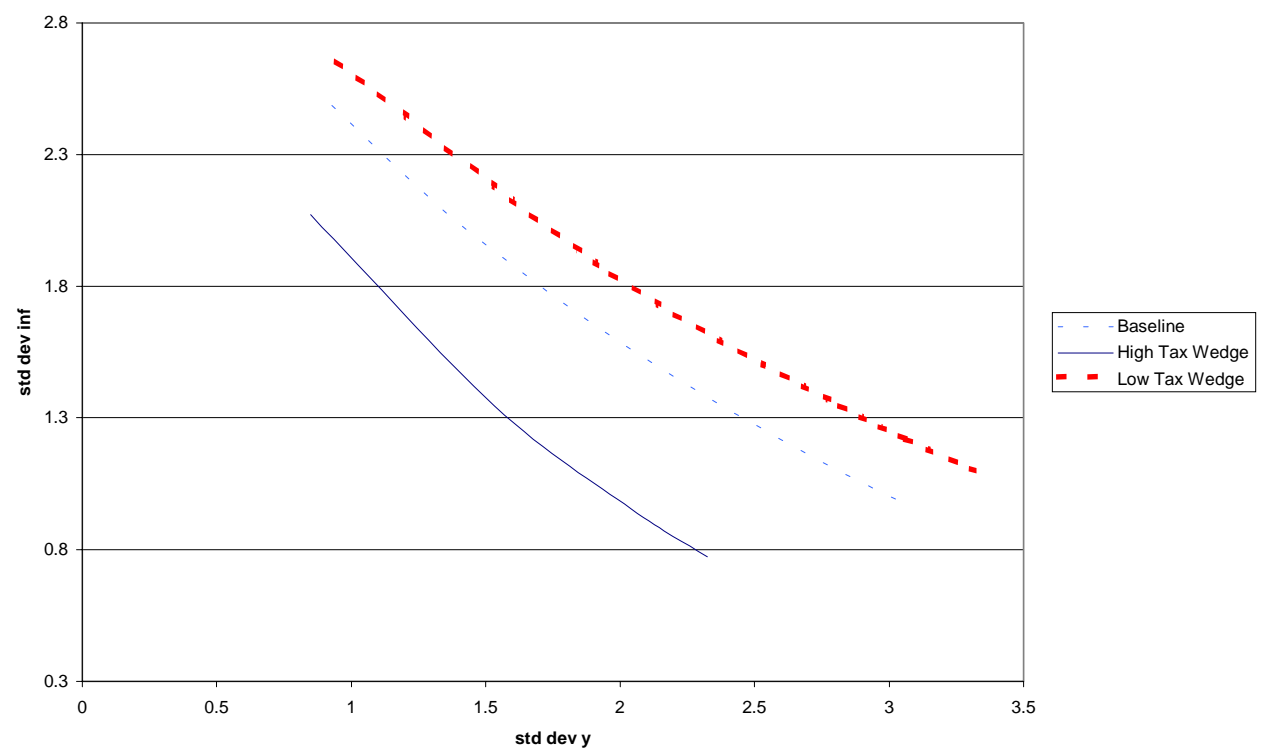

Figure 10: The Tax Wedge and Automatic Stabilizers

\subsection{The Size of the Tax Wedge}

As another robustness check, we will examine whether increasing or decreasing the size of the tax wedge in the Phillips Curve tends to improve stabilisation policy. Alongside the baseline case of $\left(\overline{T^{*}} / \overline{N\left(\frac{W}{P}\right)}+\overline{T^{*}}\right)=0.095$, we consider the impact of a high tax wedge $\left(\left(\overline{T^{*}} / \overline{N\left(\frac{W}{P}\right)}+\overline{T^{*}}\right)=0.4\right)$, and a low tax wedge $\left.\left(\overline{T^{*}} / \overline{N\left(\frac{W}{P}\right)}+\overline{T^{*}}\right)=0.01\right)$. In Figure 10 , we see that, as is intuitively obvious, increasing the size of the tax wedge tends to improve the effectiveness of countercyclical taxation policy and hence shifts the variance frontier towards the origin. This again confirms the greater role of payroll taxes in fiscal stabilisation in this model. Clearly however, there is a downside to this, as a larger tax wedge will also increase the destabilizing impact of any fiscal policy deviation from the rule. 


\section{Conclusions}

This paper has provided a first attempt to model monetary-fiscal interactions in a New Keynesian context, in which we have allowed for a much richer role for fiscal policy compared to recent contributions to this literature. This represents the first attempt, to our knowledge, to estimate a NK model which incorporates liquidity-constrained consumers on US data, and hence the impact of both government spending and taxation on the New Keynesian IS and Phillips Curve.

Having estimated this DGE model, we have conducted some preliminary analysis of the interactions between fiscal and monetary policy in such a model, to provide some understanding of the way in which different macroeconomic policy instruments interact over the business cycle.

The key conclusions which emerge from our policy analysis is that automatic stabilizers based on taxation policy seem to combine more efficiently with forward-looking inertial monetary policy rules than feedback government spending rules. This seems to be largely due to the way in which taxation (both personal and payroll taxes) enter the model, through the role played by rule-of-thumb consumers, whose consumption depends on current disposable income, but whose behaviour impacts on optimising consumers because of the presence of external habits. This causes the taxation effects to enter in difference terms in the IS curve. Interestingly, it also follows that inertia in fiscal rules may be more beneficial in taxation rules than in government spending rules, and in particular that payroll taxes, which act both through the tax wedge in the Phillips curve and through the diposable income of rule-of-thumb consumers, are the most effective fiscal stabilisation instrument. This result will be examined more systematically in further work, to examine to what extent the result is robust to changes in the specification of the model. In particular, if one were to modify the way in which nonRicardian consumers are modeled this will change the way in which taxation affects the output gap. For instance, by introducing liquidity-constrained forward-looking consumers one would introduce taxation effects in levels in the IS curve and this might attenuate some of the benefits of inertial taxation rules. Clearly introducing some form of liquidity constraint or BlanchardYaari consumers would also introduce a role for wealth, and hence another channel of monetary-fiscal interaction, through the budget identity. Similarly, introducing greater persistence in external habits might also change the impact over time of taxation on aggregate demand and might change the 
relative effectiveness of taxation and government spending. Another area which should be extended is the extent to which monetary policy design might be affected by the design of the fiscal rules. In this paper we have simply taken the monetary policy rule as that estimated from the data for the post-1982 period, but arguably the monetary authority will modify its behaviour in the light of changes in fiscal policy. So one could legitimately ask the question of how different fiscal rules will perform in the presence of optimising monetary policymakers. The difficulty of this extension is that the complexity of the framework makes it difficult to derive an appropriate welfare function for the monetary authorities, so one would need to make some assumptions regarding the form of the welfare function of the central bank (cf. Benigno and Woodford, 2003).

A full analysis of how optimal fiscal rules could be designed for a variety of different monetary policy rules, and how inertia in monetary policy impacts on the optimal design of fiscal stabilizers is potentially important. Not only in the case of the USA which was the subject of the current paper, but more significantly in the case of Euroland, where the debate on the optimal degree of fiscal activism and the limits which should be imposed on fiscal stabilizers is very open. In the UK, the discussion about the appropriate degree of fiscal activism has also been prominent in the recent Treasury Assessment on the impact on the UK of joining EMU (see Westaway, 2003), and merits further attention.

\section{Appendix: derivation of IS and Phillips curve}

We begin with the definition of total demand and total consumption:

$$
\begin{gathered}
Y_{t}=C_{t}+G_{t} \\
C_{t}=C_{t}^{R T}+C_{t}^{O}
\end{gathered}
$$

where $C_{t}^{R T}$ defines the amount of consumption by rule-of-thumb consumers and $C_{t}^{O}$ defines the amount of consumption by optimizing consumers. This is akin to Galí at al. (2002). 
From equation (4), aggregate demand from rule-of-thumb consumers amounts to:

$$
C_{t}^{R T}=\bar{N}^{R T} \frac{W_{t}}{P_{t}}+\vartheta\left(G_{t}^{T R}-T_{t}\right)
$$

where $\vartheta$ defines the proportion of rule-of-thumb consumers. (we assume that $G_{t}^{T R}-T_{t}$ is uniformly spread across consumers).

We first turn to the behavior of optimizing consumers.

From equations (1), (2), (3), assuming that all consumers' preferences and their initial holdings of financial wealth are identical, the problem can be solved as a dynamic optimization problem and we can aggregate across consumers to obtain the following intertemporal aggregate Euler condition:

$$
\frac{\left(C_{t}^{i} / H_{t}^{i}\right)^{-\rho}}{H_{t}^{i}}=E\left\{\beta \frac{\left(C_{t+1}^{i} / H_{t+1}^{i}\right)^{-\rho}}{H_{t+1}^{i}} R_{t} \frac{P_{t}}{P_{t+1}}\right\}
$$

Taking logs we obtain a first order approximation, where we also omit $\ln \beta$ as we are interested in deviations from steady state:

$$
\widehat{c_{t}^{o}}=-\left(\frac{1-\rho}{\rho}\right) \lambda\left(\widehat{c_{t-1}^{T}}-\widehat{c_{t}^{T}}\right)-\left(\frac{1}{\rho}\right)\left(\widehat{r_{t}}\right)+\widehat{c_{t+1}^{o}}
$$

where $c_{t-1}^{T}, c_{t}^{T}$ define the logs of total consumption.

Then, using the equilibrium condition for goods markets, given that we ignore investment and the external sector, we can loglinearise equation (17) in the main text

$$
Y_{t}=C_{t}+G_{t}
$$

to obtain:

$$
y_{t}=\frac{\bar{C}}{\bar{Y}} \widehat{c_{t}^{T}}+\frac{\bar{G}}{\bar{Y}} \widehat{g_{t}}
$$

where:

$$
c_{t}^{T}=\frac{\overline{C^{R T}}}{\bar{C}} \widehat{c_{t}^{R T}}+\frac{\overline{C^{o}}}{\bar{C}} \widehat{c_{t}^{O}}
$$


where $\widehat{c_{t}^{R T}}$ defines the log of total consumption by rule-of-thumb consumers:

$$
\widehat{c_{t}^{R T}}=\frac{\overline{N^{R T}} \overline{\left(\frac{W}{P}\right)}}{\overline{C^{R T}}}\left(\widehat{w_{t}-} p_{t}\right)+\vartheta\left(\overline{\frac{G_{t}^{T R}-T_{t}}{\overline{C^{R T}}}}\right)\left(G_{t}^{T R}-T_{t}\right)
$$

therefore

$$
\widehat{y_{t}}=\frac{\overline{N^{R T}} \overline{\left(\frac{W}{P}\right)}}{\bar{Y}}\left(\widehat{w_{t}-p_{t}}\right)+\vartheta\left(\frac{\overline{G_{t}^{T R}-T_{t}}}{\bar{Y}}\right)\left(G_{t}^{T R}-T_{t}\right)+\left(\frac{\overline{C^{o}}}{\bar{Y}}\right) \widehat{c_{t}^{O}}+\frac{\bar{G}}{\bar{Y}} \widehat{g}_{t}
$$

Substituting for $\widehat{c_{t}^{O}}$, we obtain

$$
\begin{aligned}
& \widehat{y_{t}}=\frac{\overline{N^{R T}}}{\bar{N}} \frac{\overline{N\left(\frac{W}{P}\right)}}{\bar{Y}}\left(\widehat{w_{t}-} p_{t}\right)+\vartheta\left(\frac{\overline{G^{T R}-T}}{\bar{Y}}\right)\left(G_{t}^{T R}-T_{t}\right)+\frac{\bar{G}}{\bar{Y}} \widehat{g}_{t}+ \\
& +\quad\left(\frac{\overline{C^{o}}}{\bar{C}}\right)\left\{-\left(\frac{1-\rho}{\rho}\right) \lambda\left[y_{t-1}-y_{t}-\frac{\bar{G}}{\bar{Y}}\left(g_{t-1}-g_{t}\right)\right]-\left(\frac{\bar{C}}{\bar{Y}} \frac{1}{\rho}\right) r_{t}\right\}+y_{t+1}-\frac{\bar{G}}{\bar{Y}} g_{t+1} \\
& -\frac{\overline{N^{R T}}}{\bar{N}} \frac{\overline{N\left(\frac{W}{P}\right)}}{\bar{Y}}\left(w_{t+1}-p_{t+1}\right)-\vartheta\left(\frac{\overline{G^{T R}-T}}{\bar{Y}}\right)\left(\widehat{G_{t+1}^{T R}-T_{t+1}}\right)
\end{aligned}
$$

Bearing in mind that

$$
\frac{\overline{C^{R T}}}{\bar{C}}=\left(1-\frac{\bar{G}}{\bar{Y}}\right)^{-1}\left[\frac{\overline{N^{R T}}}{\bar{N}} \frac{\overline{N\left(\frac{W}{P}\right)}}{\bar{Y}}+\frac{\vartheta\left(\overline{G^{T R}-T}\right)}{\bar{Y}}\right]
$$

we get:

$$
\frac{\overline{C^{o}}}{\bar{C}}=1-\frac{\overline{C^{R T}}}{\bar{C}}
$$


To complete the model we want to introduce distortionary taxes. We assume that taxes take the form of a payroll tax, $t_{P R}^{*}=\frac{\overline{T^{*}}}{\bar{N}}$ where $\bar{T}^{*}$ are the total revenues from the payroll tax. Essentially the payroll tax is divided equally between the labour force. This means that the optimizing consumer's choice between leisure and consumption is not affected. Next, we define

$$
\overline{M P L}=\frac{\bar{W}}{\bar{P}}+\frac{\overline{T^{*}}}{\bar{N}}
$$

The above expression is approximated by

$$
\widehat{m p l}=\frac{\overline{N\left(\frac{W}{\bar{P}}\right)}}{\overline{N M P L}}(\widehat{w-p})+\frac{\frac{\overline{T^{*}}}{\bar{N}}}{\overline{M P L}}\left(\widehat{t_{P R}^{*}}\right)
$$

where $\widehat{t_{P R}^{*}}=\widehat{t^{*}}-\widehat{n}$

Then bearing in mind that

$$
\ln (M P L)=\ln (1-\alpha)-\alpha \ln (N)
$$

and ignoring $\ln (1-\alpha)$ because we are interested in deviations from steady state, we get

$$
\left\{\widehat{n}\left[-\alpha+\frac{\overline{T^{*}}}{\overline{N M P L}}\right]\right\} \frac{\overline{M P L}}{\left(\frac{W}{\bar{P}}\right)}-\left(\frac{\overline{T^{*}}}{\overline{\bar{N} \frac{W}{P}}}\right)\left(\widehat{t^{*}}\right)=(\widehat{w-p})
$$

we can then substitute for $(\widehat{w-p})$ into(27) to obtain equation (10).

The derivation of the Phillips Curve for the model structure set out in the main text is outlined in detailed in Galí et al. (2001) and Leith and Malley (2002), and will not be reproduced here for reasons of space. The introduction of the payroll tax, however, changes the definition of the percentage change from steady state of the labour cost share, $\widehat{s}_{t}$. Substituting for $(\widehat{w-p})$ with

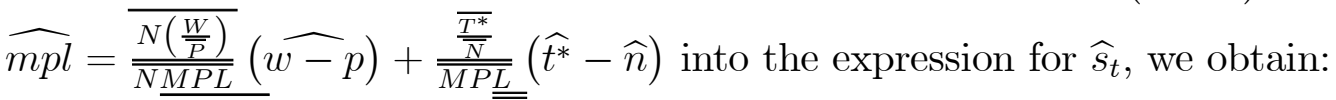

$\widehat{s}_{t}=\frac{\overline{N\left(\frac{W}{P}\right)}}{\overline{N M P L}}(\widehat{w-p})+\frac{\frac{\overline{\bar{T}^{*}}}{\bar{N}}}{\overline{M P L}}\left(\widehat{t^{*}}-\widehat{n}\right)+\widehat{n}_{t}-\widehat{y}_{t}$. This yields our modified version of the Phillips Curve including the tax wedge (11).

Data Appendix 


\subsection{Data definitions}

The data employed are quarterly observations, seasonally adjusted where available. The variables are expressed in deviations from the steady state, so real-sector variables are detrended, whilst the series on inflation and the nominal interest rate (the federal funds rate) are demeaned, using the respective sample average. For detrending, we experimented with both a HodrickPrescott filter and regression on a polynomial (cubic) trend for the real variables, and using Congressional Budget Office's and OECD (Economic Outlook) data for potential output and the output gap, respectively. The results reported use a HP trend $(\lambda=1600)$. All variables except interest rates are expressed in logs.

The government spending data $(G)$ is federal government spending excluding transfers and net interest payments, whilst we use employers' social security contributions as a proxy for payroll taxes $\left(T^{*}\right)$, and government transfers minus personal taxes as $\left(G^{T R}-T\right)$. The wage series is the index of average weekly earnings.

The output gap is defined as the (log) difference between actual and potential output. Inflation is the 4-quarter $(\log )$ difference in the Consumer Price Index. The monetary policy instrument is the Federal Funds Rate. Real series were obtained by dividing nominal series by the GDP implicit price deflator.

\subsection{Time-series' sources}

The data on actual and potential output, the implicit price deflator, federal government spending, federal (total) government debt, tax revenues, social security contributions, federal government transfers and net interest payments are from the Bureau of Economic Analysis' NIPA Tables. (See http://www.bea.doc.gov/bea/dn1.htm). Civilian employment, weekly earnings and weekly hours of work are all seasonally adjusted series from the OECD Main Economic Indicators.

Inflation is the 4-quarter (log) difference in the Consumer Price Index, derived from OECD Main Economic Indicators' CPI, all items, seasonally adjusted series. The call money rate is the Federal Funds' rate, obtained from IMF's IFS. The IMF Commodity Price Index was used to compute the rate of change of commodity prices. 


\section{R eferences}

Andres, J. and R. Domenech, 2003. "Automatic Stabilisers, Fiscal Rules and Macroeconomic Stability.", mimeo., Universidad de Valencia, January.

Benigno, P. and M. Woodford, 2003. "Optimal Monetary and Fiscal Policy: a Linear-Quadratic Approach" mimeo

Bohn, H., 1988. "The Behavior of US Public Debt and Deficits." Quarterly J ournal of E conomics, 113, pp.949-63.

Buti, M., Roeger W. and in't Veld 2001. "Stabilizing Output and Inflation in EMU: Policy Conflicts and Cooperation under the Stability Pact". J ournal of Common Market Studies, forthcoming.

Campbell, J.Y. and J.H. Cochrane, 1999. "By Force of Habit: A Consumptionbased Explanation of Aggregate Stock Market Behavior." J ournal of Political Economy, 107, 2, pp.205-51.

Carroll, C.D., 2000, "Solving Consumption Models with Multiplicative Habits." E conomics Letters, 68, pp.67-77.

Christiano, L.J., M. Eichenbaum, and C. Evans, 2001. "Nominal Rigidities and the Dynamic Effects of a Shock to Monetary Policy". NBER Working Paper \#8403.

Clarida, R., J. Galí, and M. Gertler, 1998. "Monetary policy rules in practice: some international evidence". European E conomic Review, vol. 42, no. 6, pp. 1033-1067.

Clarida, R., J. Galí, and M. Gertler, 2000. "Monetary Policy Rules and Macroeconomic Stability: Evidence and Some Theory". Quarterly J ournal of E conomics, vol. CXV, issue 1, 147-180.

Cukierman, A., and V. Anton Muscatelli, 2001. "Do Central Banks have Precautionary Demands for Expansions and for Price Stability? - Theory and Evidence". CESifo Discussion Paper n.764.

Dixit, A., Lambertini, L., 2000. "Fiscal Discretion Destroys Monetary Commitment". Working Paper, Princeton and UCLA.

Dixit, A., Lambertini, L., 2001. "Monetary-Fiscal Policy Interactions and Commitment Versus Discretion in a Monetary Union". Working Paper, Princeton and UCLA.

Erceg, C.J., D.W. Henderson, and A.T. Levin, 2000. "Optimal Monetary Policy with Staggered Wage and Price Contracts". J ournal of Monetary E conomics, 46, 281-313.

Favero, C.A. and T. Monacelli (2003). "Monetary-Fiscal Mix and Inflation Performance: Evidence from the US." CEPR Discussion Paper n.3887, 
May.

Galí, J., 2003 "New Perspectives on Monetary Policy, Inflation, and the Business Cycle" in Advances in Economic Theory, edited by: M. Dewatripont, L. Hansen, and S. Turnovsky, vol. III, 151-197, Cambridge University Press 2003.

Galí, J., and M. Gertler, 1999. "Inflation Dynamics: A Structural Econometric Analysis" J ournal of M onetary E conomics, vol. 44, $\mathrm{n}^{\circ} 2,195-222$.

Galí, J., M. Gertler and D. López-Salido, 2001. "European Inflation Dynamics". European E conomic Review, vol. 45, no 7, 1237-1270.

Galí, J., D. López-Salido, and J. Valles, 2002. "Understanding the Effects of Government Spending on Consumption." mimeo., U. Pompeu Fabra. October.

Giannoni, M.P., and M. Woodford, 2002a. "Optimal Interest-Rate Rules:

I. General Theory". NBER W orking Paper \#9419.

Giannoni, M.P., and M. Woodford, 2002b. "Optimal Interest-Rate Rules: I. Applications". NBER Working Paper \#9420.

Gordon, D.B. and E.M. Leeper, 2003. "Are Countercyclical Fiscal Policies Counterproductive?" paper presented at 5th Bundesbank Spring Conference, May.

Hansen, L. P., 1982, "Large Sample Properties of Generalized Method of Moments Estimators". E conometrica, 50, 1029-1054.

Jones, J.B., 2002, "Has Fiscal Policy Helped Stabilize the Postwar US Economy?" J ournal of M onetary E conomics, 49, 709-46.

Kara, A. and E. Nelson, 2002, "The Exchange Rate and Inflation in the UK". Bank of England, External MPC Unit, Discussion Paper n. 11.

Leith, C., and S. Wren-Lewis, 2000. "Interactions between monetary and fiscal policy rules". The E conomic J ournal, 110, C93-C108.

Leith, C., and J. Malley, 2002. "Estimated General Equilibrium Models for the Evaluation of Monetary Policy in the US and Europe". University of Glasgow Discussion Paper.

Mélitz, J., 1997. "Some Cross-Country Evidence about Debt, Deficits, and the Behaviour of Monetary and Fiscal Authorities". CEPR Discussion Paper No.1653.

Mélitz, J., 2000. "Some Cross-Country Evidence about Fiscal Policy Behaviour and Consequences for EMU". Unpublished manuscript.

Mountford, A. and Uhlig, H., 2002, "What are the effects of fiscal policy shocks?". CEPR Discussion Paper \#3338. 
Muscatelli, A., P. Tirelli and C. Trecroci, 2001. "Monetary and Fiscal Policy Interactions over the Cycle: Some Empirical Evidence". Forthcoming in R. Beetsma, C. Favero, A. Missale, V.A. Muscatelli, P. Natale and P. Tirelli (eds.), "Fiscal Policies, Monetary Policies and Labour Markets. Key Aspects of European Macroeconomic Policies after Monetary Unification". Cambridge University Press, Cambridge, United Kingdom.

Muscatelli, A., P. Tirelli and C. Trecroci, 2002. "Does institutional change really matter? Inflation targets, central bank reform and interest rate policy in the OECD countries". The Manchester School, vol. 70 (4), 2002.

Muscatelli, A., P. Tirelli and C. Trecroci, 2003. "The Interaction of Fiscal and Monetary Policies: Some Evidence using Structural Models.", CESifo W orking Paper n.1060, forthcoming, J ournal of Macroeconomics.

Perez, J.J., and P. Hiebert, 2002. "Identifying endogenous fiscal policy rules for macroeconomic models". ECB W orking Paper No. 156.

Pierse, R., 2000. W insolve, version 3.5. University of Surrey.

Sbordone, A.G., 2002. "Prices and Unit Labor Costs: A New Test of Price Stickiness". J ournal of M onetary E conomics, vol. 49 (2), pp. 265-292.

Schmitt-Grohé, S., and M. Uribe, 2001. "Optimal Fiscal and Monetary Policy Under Sticky Prices". NBER Working Paper \#9220.

Smets, F., and R. Wouters, 2002 "An Estimated dynamic stochastic general equilibrium model of the euro area", European Central Bank Working Paper n.171.

Taylor, J.B., 2000a. "The Policy Rule mix: a Macroeconomic Policy Evaluation". Unpublished manuscript, Stanford University.

Taylor, J.B., 2000b. "Reassessing Discretionary Fiscal Policy". J ournal of E conomic Perspectives, vol. 14, n.3, pp. 21-36.

von Hagen, J., Hughes Hallett, Strauch, R., 2001. "Budgetary Consolidation in EMU". E conomic Papers No. 148. March 2001. European Commission. Brussels.

Westaway, P., 2003. 'Modelling Shocks and Adjustment Mechanisms in EMU'. HM Treasury, EMU Studies.

Woodford, M., 2002. Interest and Prices: Foundations of a Theory of M onetary Policy. Princeton University Press.

Wyplosz, C., 1999. "Economic Policy Coordination in EMU: Strategies and Institutions". ZEI Policy Paper B11.

Zagaglia, P., 2002. "On (Sub)Optimal Monetary Policy Rules under Untied Fiscal Hands". Unpublished manuscript, Stockholm University. 


\section{CESifo Working Paper Series}

(for full list see www.cesifo.de)

1105 Daniel Haile, Abdolkarim Sadrieh and Harrie A. A. Verbon, Self-Serving Dictators and Economic Growth, December 2003

1106 Panu Poutvaara and Tuomas Takalo, Candidate Quality, December 2003

1107 Peter Friedrich, Joanna Gwiazda and Chang Woon Nam, Development of Local Public Finance in Europe, December 2003

1108 Silke Uebelmesser, Harmonisation of Old-Age Security Within the European Union, December 2003

1109 Stephen Nickell, Employment and Taxes, December 2003

1110 Stephan Sauer and Jan-Egbert Sturm, Using Taylor Rules to Understand ECB Monetary Policy, December 2003

1111 Sascha O. Becker and Mathias Hoffmann, Intra-and International Risk-Sharing in the Short Run and the Long Run, December 2003

1112 George W. Evans and Seppo Honkapohja, The E-Correspondence Principle, January 2004

1113 Volker Nitsch, Have a Break, Have a ... National Currency: When Do Monetary Unions Fall Apart?, January 2004

1114 Panu Poutvaara, Educating Europe, January 2004

1115 Torsten Persson, Gerard Roland, and Guido Tabellini, How Do Electoral Rules Shape Party Structures, Government Coalitions, and Economic Policies? January 2004

1116 Florian Baumann, Volker Meier, and Martin Werding, Transferable Ageing Provisions in Individual Health Insurance Contracts, January 2004

1117 Gianmarco I.P. Ottaviano and Giovanni Peri, The Economic Value of Cultural Diversity: Evidence from US Cities, January 2004

1118 Thorvaldur Gylfason, Monetary and Fiscal Management, Finance, and Growth, January 2004

1119 Hans Degryse and Steven Ongena, The Impact of Competition on Bank Orientation and Specialization, January 2004

1120 Piotr Wdowinski, Determinants of Country Beta Risk in Poland, January 2004 
1121 Margarita Katsimi and Thomas Moutos, Inequality and Redistribution via the Public Provision of Private Goods, January 2004

1122 Martin Peitz and Patrick Waelbroeck, The Effect of Internet Piracy on CD Sales: CrossSection Evidence, January 2004

1123 Ansgar Belke and Friedrich Schneider, Privatization in Austria: Some Theoretical Reasons and First Results About the Privatization Proceeds, January 2004

1124 Chang Woon Nam and Doina Maria Radulescu, Does Debt Maturity Matter for Investment Decisions?, February 2004

1125 Tomer Blumkin and Efraim Sadka, Minimum Wage with Optimal Income Taxation, February 2004

1126 David Parker, The UK's Privatisation Experiment: The Passage of Time Permits a Sober Assessment, February 2004

1127 Henrik Christoffersen and Martin Paldam, Privatization in Denmark, 1980-2002, February 2004

1128 Gregory S. Amacher, Erkki Koskela and Markku Ollikainen, Deforestation, Production Intensity and Land Use under Insecure Property Rights, February 2004

1129 Yin-Wong Cheung, Javier Gardeazabal, and Jesús Vázquez, Exchange Rate Dynamics: Where is the Saddle Path?, February 2004

1130 Alberto Alesina and Guido Tabellini, Bureaucrats or Politicians?, February 2004

1131 Gregory S. Amacher, Erkki Koskela, and Markku Ollikainen, Socially Optimal Royalty Design and Illegal Logging under Alternative Penalty Schemes, February 2004

1132 David M. Newbery, Privatising Network Industries, February 2004

1133 Charles Yuji Horioka, The Stagnation of Household Consumption in Japan, February 2004

1134 Eiji Fujii, Exchange Rate Pass-Through in the Deflationary Japan: How Effective is the Yen's Depreciation for Fighting Deflation?, February 2004

1135 Mark M. Spiegel and Nobuyoshi Yamori, Determinants of Voluntary Bank Disclosure: Evidence from Japanese Shinkin Banks, Febrary 2004

1136 Robert Dekle and Kenneth Kletzer, Deposit Insurance, Regulatory Forbearance and Economic Growth: Implications for the Japanese Banking Crisis, February 2004

1137 Takatoshi Ito and Kimie Harada, Bank Fragility in Japan, 1995-2003, February 2004

1138 Kunio Okina and Shigenori Shiratsuka, Policy Duration Effect under Zero Interest Rates: An Application of Wavelet Analysis, February 2004 
1139 Francine D. Blau and Lawrence M. Kahn, Do Cognitive Test Scores Explain Higher U.S. Wage Inequality?, February 2004

1140 Michael Rauscher, Economic Growth and Tax-Competing Leviathans, February 2004

1141 Ernst Fehr and Jean-Robert Tyran, Money Illusion and Coordination Failure, February 2004

1142 Ingo Vogelsang, Network Utilities in the U.S. - Sector Reforms without Privatization, March 2004

1143 Marc-Andreas Muendler, Estimating Production Functions When Productivity Change is Endogenous, March 2004

1144 Sascha O. Becker, Samuel Bentolila, Ana Fernandes, and Andrea Ichino, Job Insecurity and Children's Emancipation, March 2004

1145 Pascalis Raimondos-Møller and Alan D. Woodland, Non-Preferential Trading Clubs, March 2004

1146 Robert Fenge and Matthias Wrede, EU Regional Policy: Vertical Fiscal Externalities and Matching Grants, March 2004

1147 Chi-Yung Ng and John Whalley, Geographical Extension of Free Trade Zones as Trade Liberalization: A Numerical Simulation Approach, March 2004

1148 Marc-Andreas Muendler, Trade, Technology, and Productivity: A Study of Brazilian Manufacturers, 1986-1998, March 2004

1149 Eugene Beaulieu, Vivek H. Dehejia, and Hazrat-Omar Zakhilwal, International Trade, Labour Turnover, and the Wage Premium: Testing the Bhagwati-Dehejia Hypothesis for Canada, March 2004

1150 Giorgio Brunello and Francesca Gambarotto, Agglomeration Effects on EmployerProvided Training: Evidence from the UK, March 2004

1151 S. Brock Blomberg, Gregory D. Hess, and Athanasios Orphanides, The Macroeconomic Consequences of Terrorism, March 2004

1152 Bodo Sturm and Joachim Weimann, Unilateral Emissions Abatement: An Experiment, March 2004

1153 Wolfgang Ochel, Welfare-to-Work Experiences with Specific Work-First Programmes in Selected Countries, March 2004

1154 Jan K. Brueckner and Eric Pels, European Airline Mergers, Alliance Consolidation, and Consumer Welfare, March 2004

1155 Aaron Tornell, Frank Westermann, and Lorenza Martínez, NAFTA and Mexico's Economic Performance, March 2004 
1156 George Economides, Sarantis Kalyvitis, and Apostolis Philippopoulos, Do Foreign Aid Transfers Distort Incentives and Hurt Growth? Theory and Evidence from 75 Aidrecipient Countries, March 2004

1157 Robert Fenge and Volker Meier, Are Family Allowances and Fertility-related pensions Siamese Twins?, March 2004

1158 Bruno S. Frey, Simon Luechinger, and Alois Stutzer, Valuing Public Goods: The Life Satisfation Approach, March 2004

1159 Jerome L. Stein and Guay C. Lim, Asian Crises: Theory, Evidence, Warning-Signals, March 2004

1160 Romain Ranciere, Aaron Tornell, and Frank Westermann, Crises and Growth: A ReEvaluation, March 2004

1161 Assaf Razin and Efraim Sadka, Transparency, Specialization and FDI, March 2004

1162 Ludger Woessmann, How Equal Are Educational Opportunities? Family Background and Student Achievement in Europe and the United States, March 2004

1163 B.M.S. van Praag and Barbara E. Baarsma, Using Happiness Surveys to Value Intangibles: The Case of Airport Noise, March 2004

1164 Aaron Tornell, Frank Westermann, and Lorenza Martínez, The Positive Link Between Financial Liberalization, Growth, and Crises, March 2004

1165 Helge Berger and Carsten Hefeker, One Country, One Vote? Labor Market Structure and Voting Rights in the ECB, March 2004

1166 Clemens Fuest and Martin Kolmar, A Theory of User-Fee Competition, March 2004

1167 Friedrich Schneider and Robert Klinglmair, Shadow Economies around the World: What Do We Know?, April 2004

1168 Horst Raff and Nicolas Schmitt, Exclusive Dealing and Common Agency in International Markets, April 2004

1169 M. Hashem Pesaran and Allan Timmermann, Real Time Econometrics, April 2004

1170 Sean D. Barrett, Privatisation in Ireland, April 2004

1171 V. Anton Muscatelli, Patrizio Tirelli and Carmine Trecroci, Can Fiscal Policy Help Macroeconomic Stabilisation? Evidence from a New Keynesian Model with Liquidity Constraints, April 2004 